\title{
Asia-Pacific Students' Awareness and Behaviour Regarding Social Networking in the Education Sector
}

\author{
Tomayess Issa, Curtin University, Perth, Australia \\ Sulaiman Alqahtani, Curtin University, Perth, Australia \\ Theodora Issa, Curtin University, Perth, Australia \\ Noorminshah A. Iahad, Universiti Teknologi Malaysia (UTM), Johor Bahru, Malaysia \\ Peldon Peldon, Jigme Dorji Wangchuck National Referral Hospital, Thimphu, Bhutan \\ Sooyoung Kim, Seoul Women's University, Seoul, Korea \\ Samant Saurabh, Indian Institute of Technology, Jharkhand, India \\ Sumaiya Pervaizz, Curtin University, Perth, Australia \\ Sun Joo Yoo, Seowon University, Cheongju, Korea
}

\begin{abstract}
Social networking $(\mathrm{SN})$ technology has been presented to human beings as a means of communicating, collaborating, connecting, and cooperating to exchange knowledge, skills, news, chat, and to maintain contact with peers world-wide. This article examines SN awareness in the Asia-Pacific (AP) education sector (ES) with a specific focus on the advantages and disadvantages of $\mathrm{SN}$; and investigated whether AP culture influences SN adoption by the ES. An online survey was distributed to 1014 AP students and a total of 826 students responded. Several new advantages of adoption emerged from the data analysis. SN enabled students to accomplish their study tasks more quickly; it allowed them to communicate and collaborate with peers world-wide; and it fostered sustainability. The disadvantages perceived by students include depression, loneliness, and distraction, lack of interest in pursuing traditional activities, and security and privacy concerns. Finally, culture does influence SN adoption by ES institutions in AP countries.
\end{abstract}

\section{KEYWORDS}

Advantages and Disadvantages, Asia-Pacific, Awareness, Behaviour, Culture, Social Networking

\section{INTRODUCTION}

Social networking in the education sector's assessment and teaching activities has been adopted and integrated as an essential tool in recent curricula to promote students' personal and professional skills for their current studies and their future in the workforce. The use of SN in the education sector encourages students to study independently while allowing them to collaborate with their peers starting on January 13, 2021 in the gold Open Access journal, Journal of Global Information Management (converted to gold Open Access January 1, 2021), and will be distributed under the terms of the Creative Commons Attribution License (http://creativecommons.org/licenses/ by/4.0/) which permits unrestricted use, distribution, and production in any medium, provided the author of the original work and original publication source are properly credited. 
locally and globally. Students have begun to use SN to gain more knowledge about other countries, communities, issues and news, and to share their thoughts and opinions with their peers. This type of interaction will allow students to develop several skills including personal skills such as motivation, leadership, negotiation, communication, problem solving, time management, and reflection, and professional skills such as reading, writing, research, search, critical thinking, decision making, digital oral presentations, diagrammatic representations such as concept maps, and teamwork. Such skills can improve and enrich students' learning in their current studies and will be indispensable to them in the workforce. On the other hand, the use of SN has several associated disadvantages including a deterioration of basic skills such as reading and writing, depression, loneliness, distraction from studies, and lack of concentration. These disadvantages should be tackled promptly to prevent or minimize their potential harm to students. SN has transformed education systems. Classrooms have become more collaborative; this helps to create a more relaxed atmosphere among students and between them and their lecturer, since this platform encourages students to contribute their comments, concept maps, PowerPoint slides and documents. However, the use of SN in the education sector is associated with several disadvantages in terms of cognitive skills, socio-physical development, and security. This study aims to examine students' attitudes toward SN use, and to determine whether culture can influence SN adoption by students in Asia-Pacific countries (Australia, Bhutan, India, Malaysia, Pakistan and South Korea). An online survey was conducted to examine and address the research questions and aims. This paper is organized as follows: 1) Introduction; 2) Social Networking in the Higher Education; 3) SN Advantages; 4) SN Disadvantages; 5) SN use in Asia Pacific; 6) Asia-Pacific -Cultural Orientation based on Hofstede's cultural framework; 7) Research Method and Questions; 8) Participants; 9) Results, Discussion; 10) New Theoretical Findings and Contribution; 1) Limitations, and 12) Conclusion.

\section{SOCIAL NETWORKING IN THE HIGHER EDUCATION}

In the 21st century, SN has become an essential tool that allows stakeholders ranging from individuals to organisations to communicate, connect, collaborate and cooperate with their peers, colleagues or community both locally and globally in order to exchange knowledge and useful information. Social networking websites and services include Myspace, Facebook, YouTube, LinkedIn, Twitter, Wikis, Blogs and Podcasts, Instant Messaging, Mashups and Virtual World. They allow stakeholders to interact, intermingle, share and communicate, and to exchange opinions, advice and philosophies regarding numerous subjects (De-Marcos, Domínguez, Saenz-de-Navarrete, \& Pagés, 2014; DeKay, 2009; Holmes \& O’loughlin, 2014; Park, Kee, \& Valenzuela, 2009; Waters, Burnett, Lamm, \& Lucas, 2009).

The education sector in the Asia-Pacific region has started to integrate SN especially in assessments and learning/teaching activities. One reason for this implementation is that it allows students to become independent learners and enhance their professional and personal skills which are needed for their current studies and for their future in the workforce. Furthermore, the most important reason for this implementation is that $\mathrm{SN}$ can make classes more interactive, creative and engaging, fostering a friendly and close rapport between students and lecturer.

By the same token several authors (Durak, 2017; Gülbahar, Rapp, Kilis, \& Sitnikova, 2017) indicate that using SN in higher education will enhance communication, collaboration, participation and sharing information and discussion with colleagues and peers. Furthermore, SN will promote and enhance critical thinking and decision making and facility personalized learning.

Furthermore, several studies (Chugh \& Ruhi, 2018; Peruta \& Shields, 2017) point out that SN adoption in the higher education has shifted the way communication and collaboration take place between the students and academics to exchange knowledge, ideas, thoughts and opinions in an informal way, and SN use is significant to attract and retain students. Students can easily interact with SN technology, since the SN interface is efficient, effective, and easy to learn, remember and use. 
Students can upload their work in various formats including PDF, video, PowerPoint slides, concept maps, and images. These formats allow students to comment on and provide feedback regarding the contents, style and layout. Furthermore, communication, collaboration and cooperation will be developed between the students themselves and the lecturer.

Our teaching experience indicates that this type of collaboration makes the learning and teaching activities more innovative, imaginative and engaging. The current literature (Blatt, 2015; Dillenbourg, 1999; Frydenberg, 2008; Kontos, Emmons, Puleo, \& Viswanath, 2010; Ku, Tseng, \& Akarasriworn, 2013; Langheinrich \& Karjoth, 2010; Lin \& Lu, 2011; McCarroll \& Curran, 2013; Minocha \& Thomas, 2007; Moreno \& Kolb, 2012; Pan, Xu, Wang, Zhang, Ling, \& Lin, 2015; Tharp, 2010; Tsinakos, 2006; Wang, 2008) indicates that SN applications are essential in any sector including that of education, as these applications inspire the learning process and collaboration among the students and lecturers, as students can share their knowledge, understanding and experiences and sentiments. Integrating SN in the education sector will improve students' self-confidence, facilitate knowledge transfer and problem solving, and enhance the effectiveness of learning and teaching activities. Therefore, academics should take this opportunity, and commence to incorporate SN in assessments and activities. They need to know how to integrate SN correctly by employing learning theories and models to improve students' learning outcomes.

\section{SN ADVANTAGES}

Several studies have indicated (Din, Yahya, Suzan, \& Kassim, 2012; Forrester Research, 2010; Issa, 2016; Kelin, 2008; Kiehne, 2004; Lin \& Lu, 2011; Mathew, 2014; McCarroll \& Curran, 2013; McKenna, 2010; Moreno \& Kolb, 2012; Oh, Ozkaya, \& LaRose, 2014; Pempek, Yermolayeva, \& Calvert, 2000; Zhu, Chang, Luo, \& Li, 2014) that SN applications offer several advantages: sharing of cutting edge knowledge; collaboration; inter-crossing relationships; communication skills; environment-friendly and new acquaintances can be made. Figure 1 shows the advantages of SN applications in greater detail.

\section{SN DISADVANTAGES}

The use of SN applications in the education sector can create some disadvantages concerning students' cognitive, social and physical development, and security. Figure 2 shows the major disadvantages of SN applications in details, while Figure 4 illustrates the SN disadvantages in more detail (Clarke, 2010; Din et al., 2012; Fox \& Moreland, 2015; Issa, 2016; Johnson \& Knobloch-Westerwick, 2014; Kontos et al., 2010; Langheinrich \& Karjoth, 2010; Mathew, 2014; Moreno \& Kolb, 2012; Steinfield, DiMicco, Ellison, \& Lampe, 2009 ; Velasquez, Graham, \& McCollum, 2009 ). Finally, Figure 1 and 2 present the online survey questions.

\section{SN USE IN ASIA PACIFIC}

SN applications are common in the education sector in some countries such as Australia, but in other Asia-Pacific countries, they are still in the initial stages. Currently, countries in the Asia-Pacific region are using the Internet, social networking and mobile technology intensively.

According to Kepios (2017), in Australia, more than two million in a population of 24 million are actively engaged in social networking; while in Bhutan it is more than 70 thousand from one million. In India more than 61 million from 1.3 billion are using social networking; whereas in Malaysia, more than four million from 31 million are active SN users. Moreover, in Pakistan three million from 193 million are using social networking. Finally, in South Korea, one million from 51 million are active in social networking. 
Figure 1. SN advantages in detail - prepared by researchers

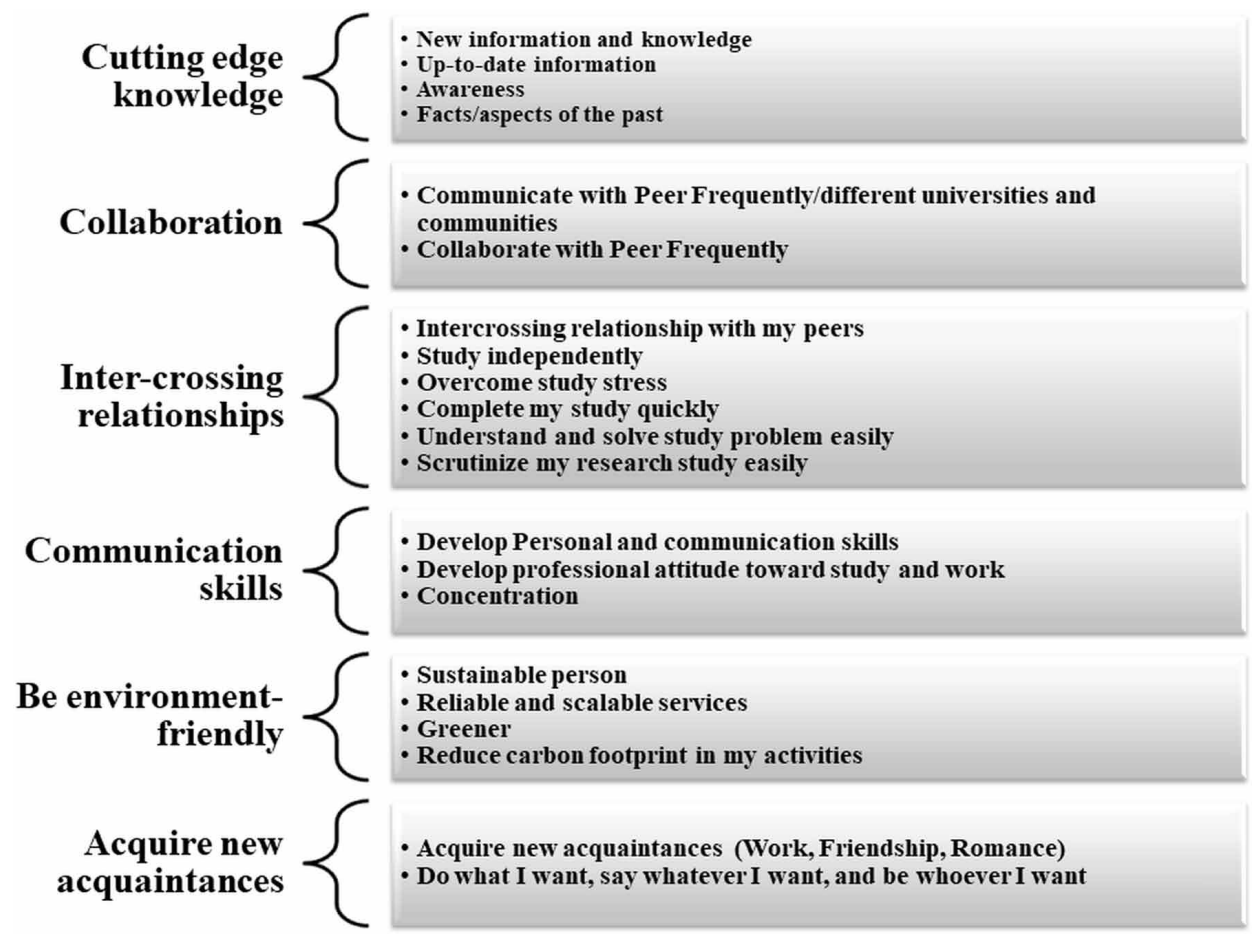

Figure 2. SN disadvantages in detail- prepared by researchers

development $\left.\begin{array}{l}\text { Cognitive } \\ \text { development }\end{array}\right\} \begin{aligned} & \text { - Prevents me from concentrating on writing and reading skills } \\ & \text { - Prevents me from the fundamental knowledge and skills } \\ & \text { - Scatters my attention } \\ & \text { - Decreased my grammar, proofreading, and deep thinking skills } \\ & \text { - Distraction }\end{aligned}$


The Asia-Pacific studies (Abdulahi, Samadi, \& Gharleghi, 2014; Heller Baird \& Parasnis, 2011; Kuzma, 2010; Lipp, Davis, Peter, \& Davies, 2014; Miller \& Lammas, 2010; Peluchette \& Karl, 2008; Peng \& Zhou, 2005; Phua \& Jin, 2011; Shin \& Harman, 2009; Sigman, 2009; Tariq, Mehboob, Asf, \& Khan, 2012; Trusov, Bucklin, \& Pauwels, 2009) discuss the Internet and SN technology use on marketing, among individuals and Internet and technology in the education sector to improve students' interaction and collaboration among their colleagues and unit-coordinator.

To the best of our knowledge, none of the research from the Asia-Pacific discussed the SN inspiration for students from the awareness, advantages, disadvantages, and culture, especially from the education sector perspective. Therefore, the current literature review in the AP is limited to examining students' reaction toward Internet and SN use. However, this study aims to examine the AP students' perspective, behaviour and performance regarding the use of $\mathrm{SN}$ in the education sector and students' awareness of sustainability.

Therefore, in order to integrate this technology in the education sector, especially in the AsiaPacific region, specific standards and guidelines need to be followed by academics and teaching and learning departments in order to maximise the advantages and mitigate or eliminate the disadvantages.

Finally, SN usage in the education sector globally or in the Asia-Pacific region will bring several advantages to students, as mentioned previously. Hence, the appropriate introduction and implementation of technology in tertiary institutions will ensure that students, unit coordinators and the administration will benefit, and that the associated disadvantages will be mitigated.

\section{ASIA-PACIFIC - CULTURAL ORIENTATION BASED ON HOFSTEDE'S CULTURAL FRAMEWORK}

From the cultural perspective, several studies (Clark, 2010; Heydari \& Laroche, 2017; Hudson, Huang, Roth, \& Madden, 2016; Lowry, Zhang, Zhou, \& Fu, 2010; Ngai, Tao, \& Moon, 2015; Papacharissi, 2010; Stump \& Gong, 2017; Wallace \& Brooks, 2015) have examined and assessed how cultural contexts shape the use of technology including social networking. From the marketing perspective, studies have investigated consumer-brand relationships, technology adoption, and the self-control effect of difference in terms of the six dimensions of Hofstede's cultural framework (Hofstede, 1984, 2003) (i.e., power distance, long-term orientation, individualism, masculinity, indulgence, and uncertainty avoidance).

To the best of our knowledge, none of the studies has examined the use of social networking in the Asia-Pacific education sector, particularly in regard to its advantages and disadvantages. Therefore, this study aims to identify and determine if the Asia-Pacific culture will be influenced by $\mathrm{SN}$ adoption in the education sector by examining if the Asia-Pacific students are sharing same advantages or disadvantages by using the SN.

Therefore, to examine and assess the cultural orientation in the Asia-Pacific countries chosen for this study, the researchers applied Hofstede's cultural framework comprising six dimensions by comparing the six countries in this study using the Hofstede Insights (2018) website.

Figure 3 indicates that the power distances for Malaysia and Bhutan are very high compared to those in India, South Korea, Pakistan and Australia. This is significant since low power distance allows students to participate in decisions that affect them.

Australia has a high score for Individualism compared to other countries; this means that Australians are expected to take care of themselves and their immediate families. On the other hand, Pakistan, South Korea and Malaysia have the lowest scores. Collectivism is the descriptive term applied to a group that has a low score for Individualism; members of this group strive to develop and consolidate relationships with their extended families and others within the group. Moreover, they are expected to support each other when challenged by risks and conflicts. 
Figure 3. Comparison of Asia-Pacific countries - adopted from the Hofstede Insights website. Prepared by researchers.

Asia-Pacific-Cultural Orientation based on Hofstede's cultural framework

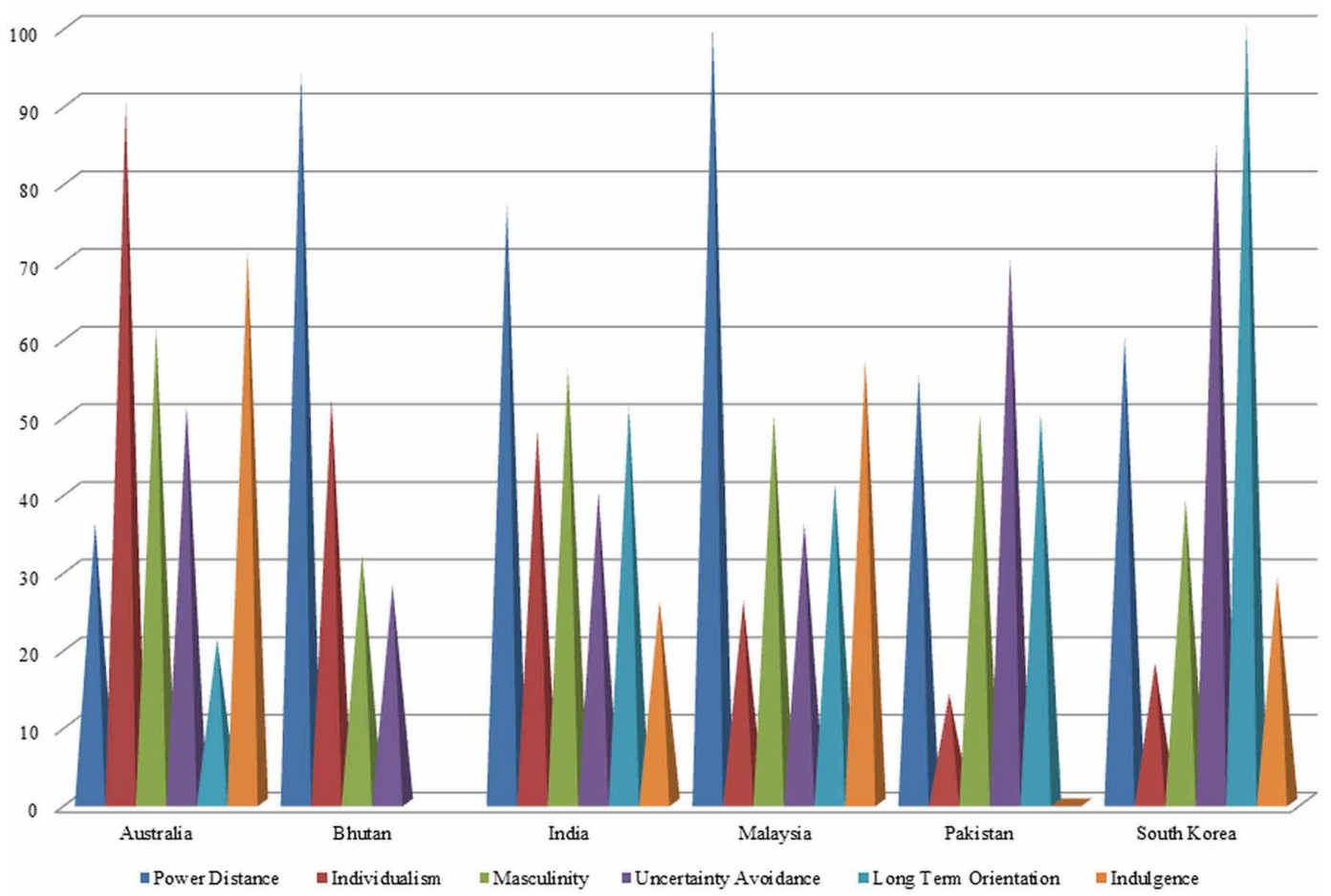

Furthermore, a high score for the Masculinity dimension indicates that the society will be driven by competition. Figure 3 shows that Australia, India, Malaysia, Pakistan scored 61, 56, 50 and 50 percent respectively, compared to South Korea and Bhutan with scores of 39 and 32 respectively. A low score for the Masculinity dimension means that the dominant values in that society emphasize the care of others and the quality of life.

Regarding the Uncertainty Avoidance dimension, Pakistan and South Korea had the highest scores compared to other countries. These cultures are industrious and productive, so innovation and security are significant elements of individual enthusiasm.

For the Long-Term Orientation dimension, South Korea scored 100 percent compared to Australia with 21 percent. This means that low-scoring countries prefer traditions and norms, while countries with high scores encourage a robust and innovative education system as a way of preparing for the future.

Finally, for the Indulgence dimension, Australia scored 71 percent. This indicates that Australian people tend to give in to their impulses and desires with regard to enjoying life and having fun. However, those countries with low indulgence scores are considered to be restrained, meaning that individuals and society in general (e.g. India and South Korea) control and overcome their desires by means of strict social norms (Hofstede, 1984, 2003; Hofstede Insights, 2018; Matusitz \& Musambira, 2013).

Finally, this study contributes new significance and findings to the current literature by examining students' attitudes toward and opinions about the use of SN, thereby identifying new advantages and disadvantages from the perspective of the Asia-Pacific education sector. In addition, this study will confirm whether the cultural contexts of Asia-Pacific nations will influence SN adoption, especially in the education sector in terms of Hofstede's cultural framework. 


\section{RESEARCH METHOD AND QUESTIONS}

This study aims to answer these questions: "What are the advantages and disadvantages of SN use in ES institutions in Asia-Pacific countries? How can Asia-Pacific cultures influence SN adoption by tertiary students in this region? In order to answer these questions, an online survey was developed based on the literature. The survey comprised three sections: background of the respondents, perceived benefits of SN, and perceived disadvantages of SN. For the benefits section, the main researcher developed twenty-five statements based on the literature review. These statements related to cutting edge knowledge, collaboration, inter-crossing relationships, communication skills, being environmentfriendly and making new acquaintances. For the disadvantages section, the main researcher developed thirty statements based on the literature review. These statements concerned cognitive development, social development, physical development, and security.

A five-point Likert scale was used for each part of the online survey to "examine how strongly subjects agree or disagree with statements" (Sekaran, 2003, p. 197). The five-point Likert scale range was: Strongly Disagree, Disagree, Neutral, Agree, and Strongly Agree (Likert, 1932). Likert scale is used in the online survey to measure the strength of a respondent's perceived agreement or disagreement to statements. In the Five Likert scale the value three is the neutral position, while one and five are the two extremes. (Sohmee \& Oppeniander, 2010, p. 15)

In the online survey, the main researcher provided clear instructions at the top of the page and a progress bar along the bottom to indicate to participants their proximity to the finishing point. Finally, the main researcher presented three questions per page to minimize scrolling, and a 'thank you' message was presented at the end to acknowledge the respondents' participation. The online survey was distributed via email, Facebook, WhatsApp, LinkedIn and the university portal system. The survey received ethics approval from the main researcher's university, and was distributed to the researchers in Bhutan, India, Malaysia, Pakistan and South Korea. The data for Australia was collected via Qualtrics within three weeks. The online survey results were analyzed using SPSS version 24. The online survey data was collected for a period of six to eight months from the AP countries.

General speaking, the online survey is considered the most sophisticated tool for collecting participants' responses, but in order to collect a high rate of responses, researchers should provide accurate guidelines and instructions to the participants, and a follow-up message should be sent after the first distribution phase. Online surveys are easy, inexpensive and anonymous. On the other hand, due to technical issues such as viruses and hacking, the response rate may be less than anticipated (Couper, Traugott, \& Lamias, 2001; Dillman, D, 2007; Dillman, D, Glenn, Tortora, Swift, Kohrell, Berck, \& Messer, 2009; Dillman, Reipus, \& Matzat, 2010; Dillman, 2017; Fan \& Yan, 2010; Smyth, Dillman, Christian, \& O’Neill, 2010; Toepoel \& Dillman, 2008; Umbach, 2004).

\section{PARTICIPANTS}

This study targeted several countries in the Asia-Pacific region, namely Australia, Bhutan, India, Malaysia, Pakistan and South Korea. This study selected these countries since they are located in the same region, and some countries are sharing the same culture and attitude. An online survey was distributed to tertiary students. Of the 1014 Asia-Pacific students, 826 completed the whole survey, with response rates of $100 \%, 80 \%, 52 \%, 68 \% 82 \%$ and $96 \%$ respectively. The online survey was distributed via several channels including email and social networking sites such as Facebook, LinkedIn, What's up and other facilities; however, the data for Australia was collected via Qualtrics. Table 1 shows the statistics for Gender, Age, Qualifications, number of hours spent daily on social networking (not including email), number of hours per day spent on the Internet for email, and finally, the participants' reason(s) for using the Internet. Table 1 indicates that Pakistan had the highest number of male respondents 75\% (139 respondents) while South Korea had the highest number of female respondents $75 \%$ (180 respondents). 
Table 1. Online survey statistics Asia Pacific - prepared by researchers

\begin{tabular}{|c|c|c|c|c|c|c|}
\hline $\begin{array}{l}\text { Number and Percentage of } \\
\text { Online Survey }\end{array}$ & Australia & Bhutan & India & Malaysia & Pakistan & South Korea \\
\hline Questionnaires Distributed & 153 & 163 & 162 & 109 & 186 & 241 \\
\hline Questionnaires Returned & 153 & 130 & 85 & 74 & 153 & 231 \\
\hline Response Rate & $100 \%$ & $80 \%$ & $52 \%$ & $68 \%$ & $82 \%$ & $96 \%$ \\
\hline \multicolumn{7}{|l|}{ Gender } \\
\hline Male Respondents & $63(41 \%)$ & $93(57 \%)$ & $125(77 \%)$ & $55(50 \%)$ & $139(75 \%)$ & $61(25 \%)$ \\
\hline Female Respondents & $90(59 \%)$ & $70(43 \%)$ & $37(23 \%)$ & $54(50 \%)$ & $47(25 \%)$ & $180(75 \%)$ \\
\hline \multicolumn{7}{|l|}{ Age } \\
\hline $18-22$ & $21(14 \%)$ & $83(51 \%)$ & $54(31 \%)$ & $43(39 \%)$ & $93(50 \%)$ & $116(48 \%)$ \\
\hline $22-32$ & $44(29 \%)$ & $64(39 \%)$ & $84(48 \%)$ & $50(46 \%)$ & $78(42 \%)$ & $112(47 \%)$ \\
\hline $32-42$ & $42(27 \%)$ & $14(9 \%)$ & $29(17 \%)$ & $15(14 \%)$ & $12(14 \%)$ & $7(3 \%)$ \\
\hline $42-52$ & $46(30 \%)$ & $1(1 \%)$ & $7(4 \%)$ & $1(1 \%)$ & $1(1 \%)$ & $5(2 \%)$ \\
\hline Over 52 & 0 & $1(1 \%)$ & $1(1 \%)$ & 0 & $21(\%)$ & 0 \\
\hline \multicolumn{7}{|l|}{ Qualifications } \\
\hline Primary Education & $57(39 \%)$ & $1(0.7 \%)$ & $18(11 \%)$ & 0 & $4(2 \%)$ & 0 \\
\hline Higher Secondary /Pre-University & $13(9 \%)$ & $34(22.5 \%)$ & $6(4 \%)$ & $13(13 \%)$ & $21(12 \%)$ & $187(78 \%)$ \\
\hline Professional Certificate & $18(12 \%)$ & $5(3.3 \%)$ & $13(8 \%)$ & $1(1 \%)$ & $7(4 \%)$ & 0 \\
\hline Diploma & $6(4 \%)$ & $53(35.1 \%)$ & $20(12 \%)$ & $2(2 \%)$ & $8(5 \%)$ & 0 \\
\hline $\begin{array}{l}\text { Advanced/Higher/Graduate } \\
\text { Diploma }\end{array}$ & $36(25 \%)$ & 0 & $11(7 \%)$ & $3(3 \%)$ & $7(4 \%)$ & 0 \\
\hline Bachelor's Degree & $4(3 \%)$ & $53(35.1 \%)$ & $55(33 \%)$ & $50(51 \%)$ & $105(60 \%)$ & $50(21 \%)$ \\
\hline Post Graduate Diploma & $11(8 \%)$ & $3(2.0 \%)$ & $9(5 \%)$ & $2(2 \%)$ & $5(3 \%)$ & $1(0.42 \%)$ \\
\hline Master's Degree & 0 & $2(1.3 \%)$ & $33(20 \%)$ & $27(28 \%)$ & $18(10 \%)$ & $1(0.42 \%)$ \\
\hline $\mathrm{PhD}$ & 0 & 0 & 0 & 0 & 0 & 0 \\
\hline Others & 0 & 0 & 0 & 0 & 0 & 0 \\
\hline \multicolumn{7}{|c|}{ Hours you spend on the social networking daily, not including email (per day). } \\
\hline Less than an hour & $81(53 \%)$ & $91(61 \%)$ & $84(61 \%)$ & $23(24 \%)$ & $93(54 \%)$ & $89(37 \%)$ \\
\hline Up to five hours & $52(34 \%)$ & $51(34 \%)$ & $50(36 \%)$ & $49(52 \%)$ & $58(34 \%)$ & $126(53 \%)$ \\
\hline Five to ten hours & $11(7 \%)$ & $7(5 \%)$ & $2(1 \%)$ & $18(19 \%)$ & $12(7 \%)$ & $19(8 \%)$ \\
\hline Ten to twenty hours & $7(5 \%)$ & 0 & $1(1 \%)$ & $3(3 \%)$ & $7(4 \%)$ & $4(2 \%)$ \\
\hline Over twenty hours & $2(1 \%)$ & $1(1 \%)$ & 0 & $1(1 \%)$ & $3(2 \%)$ & 0 \\
\hline \multicolumn{7}{|c|}{ Hours you spend on the Internet for email (per day). } \\
\hline Less than an hour & $82(54 \%)$ & $118(79 \%)$ & $100(73 \%)$ & $67(71 \%)$ & $136(79 \%)$ & $207(87 \%)$ \\
\hline Up to five hours & $53(35 \%)$ & $24(16 \%)$ & $25(18 \%)$ & $15(16 \%)$ & $26(15 \%)$ & $29(12 \%)$ \\
\hline Five to ten hours & $14(9 \%)$ & $4(3 \%)$ & $11(8 \%)$ & $9(10 \%)$ & $5(3 \%)$ & 0 \\
\hline Ten to twenty hours & $1(1 \%)$ & $2(1 \%)$ & $1(1 \%)$ & $2(2 \%)$ & $3(2 \%)$ & $1(0.4 \%)$ \\
\hline Over twenty hours & $3(2 \%)$ & $2(1 \%)$ & 0 & $1(1 \%)$ & $3(2 \%)$ & 0 \\
\hline
\end{tabular}




\begin{tabular}{|l|l|l|l|l|l|l|}
\hline \multicolumn{1}{|c|}{$\begin{array}{c}\text { Number and Percentage of } \\
\text { Online Survey }\end{array}$} & \multicolumn{1}{|c|}{ Australia } & \multicolumn{1}{|c|}{ Bhutan } & \multicolumn{1}{|c|}{ India } & \multicolumn{1}{|c|}{ Malaysia } & \multicolumn{1}{l|}{ Pakistan } & South Korea \\
\hline You use the Internet to: (you can choose more than one option) \\
\hline Email & $139(18 \%)$ & $96(20 \%)$ & $123(16 \%)$ & $83(17 \%)$ & $134(19 \%)$ & $133(13 \%)$ \\
\hline Play Games & $54(7 \%)$ & $30(6 \%)$ & $29(4 \%)$ & $26(5 \%)$ & $53(7 \%)$ & $49(5 \%)$ \\
\hline Study & $65(8 \%)$ & $121(25 \%)$ & $119(15 \%)$ & $88(18 \%)$ & $136(19 \%)$ & $190(18 \%)$ \\
\hline Work & $65(8 \%)$ & $57(12 \%)$ & $70(9 \%)$ & $46(9 \%)$ & $92(13 \%)$ & $45(4 \%)$ \\
\hline Shop Online & $96(12 \%)$ & $2(0.4 \%)$ & $86(11 \%)$ & $29(6 \%)$ & $32(4 \%)$ & $149(14 \%)$ \\
\hline Chat & $54(7 \%)$ & $107(22 \%)$ & $95(12 \%)$ & $63(13 \%)$ & $117(16 \%)$ & $56(5 \%)$ \\
\hline Research Hobbies & $64(8 \%)$ & $41(8 \%)$ & $62(8 \%)$ & $33(7 \%)$ & $43(6 \%)$ & $134(13 \%)$ \\
\hline Bank Online & $102(13 \%)$ & $6(1 \%)$ & $65(8.4 \%)$ & $50(10 \%)$ & $29(4 \%)$ & $72(7 \%)$ \\
\hline Buy goods or services & $78(10 \%)$ & $1(0.2 \%)$ & $43(6 \%)$ & $23(5 \%)$ & $28(4 \%)$ & $107(10 \%)$ \\
\hline Buy stocks or investing online & $14(2 \%)$ & 0 & $7(1 \%)$ & $3(1 \%)$ & $11(2 \%)$ & $9(1 \%)$ \\
\hline $\begin{array}{l}\text { Make or research travel information } \\
\text { or reservations }\end{array}$ & $55(7 \%)$ & $13(3 \%)$ & $65(8 \%)$ & $44(9 \%)$ & $25(3 \%)$ & $70(7 \%)$ \\
\hline Others - Please specify & $7(1 \%)$ & $10(2 \%)$ & $8(1 \%)$ & $5(1 \%)$ & $15(2 \%)$ & $38(4 \%)$ \\
\hline
\end{tabular}

Furthermore, most of the participants ranging in age from 18-22 were from Bhutan, Pakistan and South Korea at $83(51 \%), 93(50 \%)$ and $116(48 \%)$ respectively. While the ages range from 22-32 were from India, Pakistan and South Korea at 84 (48\%), 78(42\%) and 112(47\%) correspondingly. Australia had the highest in age range 32-42 and 42-52 at $42(27 \%)$ and $46(30 \%)$ respectively. In regard to the participants' qualifications, South Korea had the greatest number of participants in the higher secondary/pre-university level with 187 (78\%) participants, Australia had the highest number for the advanced higher graduate diploma with 36(25\%) participants; and Pakistan had the highest number of participants with the bachelor's degree with 105(60\%) participants. Finally, India had the highest number of participants with a master's degree. The online survey results indicated that participants from Pakistan, Bhutan, and South Korea spend less than an hour on social networking with 93 (54\%), 91(61\%) and 89(37\%) participants correspondingly. However, $126(53 \%)$ participants from South Korea spend up to five hours on social networking. On the other hand, participants in South Korea, Pakistan, and Bhutan spend less than an hour using the Internet for email (per day) at 207(87\%), $136(79 \%)$ and $118(79 \%)$ respectively. Furthermore, Australia had the highest number (53 (35\%)) of participants spending up to five hours per day on the Internet for email use. Furthermore, the majority of participants indicated that they used the Internet for email, study, shop online, chatting, research and banking online; as for the "other" option, participants indicated that they used the Internet for watching movie, TV and YouTube, and listening to music.

\section{RESULTS AND DISCUSSION}

In this section, results, discussion and limitations will be presented and discussed to determine whether or not the study aims were achieved. Both Tables 2 and 3 show the results of Cronbach's Alpha, KMO and Barlett's test for the social networking advantages and disadvantages. For the advantages, the Cronbach's Alpha for all 25 variables was .961, .950, .904, .919, .938, .888 and .926 for Australia, Bhutan, India, Malaysia, Pakistan, South Korea and all countries in the Asia-Pacific region, respectively. The Alpha result indicates an excellent internal consistency of the items in the scale (Bland \& Altman, 1997; Bravo \& Potvin, 1991; Connelly, 2011; Tavakol \& Dennick, 
Table 2. Advantages - Cronbach's Alpha, KMO and Bartlett's test - prepared by researchers

\begin{tabular}{|l|l|l|l|}
\hline \multicolumn{1}{|c|}{ Country } & \multicolumn{1}{c|}{ Cronbach's Alpha } & KMO & \multicolumn{1}{c|}{ Bartlett's Test } \\
\hline Australia & .961 & .920 & $\chi^{\wedge} 2=3420.299, \mathrm{df}=300, \mathrm{p}<.000$ \\
\hline Bhutan & .950 & .912 & $\chi^{\wedge} 2=1981.573, \mathrm{df}=300, \mathrm{p}<.000$ \\
\hline India & .904 & .804 & $\chi^{\wedge} 2=1242.529 \mathrm{df}=300, p<.000$ \\
\hline Malaysia & .919 & .732 & $\chi^{\wedge} 2=1234.436 \mathrm{df}=300, \mathrm{p}<.000$ \\
\hline Pakistan & .938 & .873 & $\chi^{\wedge} 2=2434.196 \mathrm{df}=300, \mathrm{p}<.000$ \\
\hline South Korea & .888 & .843 & $\chi^{\wedge} 2=2387.333 \mathrm{df}=300, \mathrm{p}<.000$ \\
\hline Total all Countries & .926 & .919 & $\chi^{\wedge} 2=8581.140 \mathrm{df}=300, \mathrm{p}<.000$ \\
\hline
\end{tabular}

Table 3. Disadvantages - Cronbach's Alpha, KMO and Bartlett's test - prepared by researchers

\begin{tabular}{|l|l|l|l|}
\hline \multicolumn{1}{|c|}{ Country } & \multicolumn{1}{c|}{ Cronbach's Alpha } & KMO & \multicolumn{1}{c|}{ Bartlett's Test } \\
\hline Australia & .970 & .924 & $\chi^{\wedge} 2=4498.143, \mathrm{df}=435, \mathrm{p}<.000$ \\
\hline Bhutan & .948 & .868 & $\chi^{\wedge} 2=2620.397, \mathrm{df}=435, \mathrm{p}<.000$ \\
\hline India & .941 & .799 & $\chi^{\wedge} 2=1964.200, \mathrm{df}=435, \mathrm{p}<.000$ \\
\hline Malaysia & .944 & .821 & $\chi^{\wedge} 2=1989.899, \mathrm{df}=435, \mathrm{p}<.000$ \\
\hline Pakistan & .950 & .900 & $\chi^{\wedge} 2=3165.904, \mathrm{df}=435, \mathrm{p}<.000$ \\
\hline South Korea & .909 & .857 & $\chi^{\wedge} 2=3460.030, \mathrm{df}=435, \mathrm{p}<.000$ \\
\hline Total all Countries & .935 & .916 & $\chi^{\wedge} 2=11274.267, \mathrm{df}=435, \mathrm{p}<.000$ \\
\hline
\end{tabular}

2011). Kaiser-Meyer-Olkin measures of sampling adequacy of .920, .912, .804, .732, .873, .843, and .919 were obtained for Australia, Bhutan, India, Malaysia, Pakistan, South Korea, respectively; hence, all countries, had a good sample size for the analysis, and since the KMO was .9 and above, .8 and .7, this indicated that an adequate sample was obtained for the analysis, and the KMO was interpreted as a 'marvelous,' 'meritorious,' and 'middling' result (Frohlich \& Westbrook, 2001; Hill, 2012). Regarding the disadvantages, the Cronbach's Alpha for all 30 variables was $.970, .948$, $.941, .944, .950, .909$ and .935 , for Australia, Bhutan, India, Malaysia, Pakistan, South Korea and the total of all the Asia-Pacific countries in this study respectively, indicating the excellent internal consistency of the items in the scale (Bravo \& Potvin, 1991; Gliem \& Gliem, 2003). A KaiserMeyer-Olkin measure of sampling adequacy of $.924, .868, .799, .821, .900, .857$, and .916 obtained for Australia, Bhutan, India, Malaysia, Pakistan, South Korea and all countries in Asia-Pacific, respectively, indicated a good sample size was obtained for the analysis, and since the KMO was .9 and above, .8 and .7 this was considered a 'marvellous', 'meritorious' and 'middling' result (Hill, 2012; Williams, Onsman, \& Brown, 2010). Furthermore, the Bartlett's test of sphericity for the advantages was highly significant for Australia, Bhutan, India, Malaysia, Pakistan, South Korea, as well as for all the Asia-Pacific countries chosen for this study, as the items of the scale were sufficiently correlated for factors to be found (Burns \& Burns, 2008; Schaefer, Larson, Davidson, \& Coan, 2014). Finally, Bartlett's test of sphericity for the Disadvantages aspects was highly significant for Australia, Bhutan, India, Malaysia, Pakistan, South Korea, as well as for the total of all Asia-Pacific countries in this study, indicating that the items in the scale were sufficiently 
correlated for factors to be found (Burns \& Burns, 2008; Das, Dash, Sahoo, \& Mohanty, 2017; Dziuban \& Shirkey, 1974; Tobias \& Carlson, 1969).

Furthermore, to access the regression coefficients (i.e. slopes), factor loading was carried out to examine the advantages and disadvantages for social networking in Asia-Pacific, the factor loadings for both advantages and disadvantages were high enough to be considered as important (Costello \& Osborne, 2005). Several items were excluded under factors where the factor loading was below 0.5 based on the rule of thumb of Stevens (1992) for a sample size above 100. The results which were produced from SPSS (version 24) generated two to three new advantages for each country as well as for all countries (see Table 4). It came to our attention that Asia-Pacific students indicated that SN assists them to make new acquaintances, acquire cutting edge knowledge and awareness locally and globally, encourages them to study independently and makes them sustainable people. Furthermore, communication and collaboration with peers are increased as SN usage is considered an essential tool for study and research, especially for students in South Korea. The most interesting results from this study came from students in Australia and Malaysia who indicated that via SN use, they have become more sustainable and greener; on the other hand, South Korean students expressed that SN helped to form romantic attachments. These new advantages justified the study aims, and answered the first research question: that using SN in education sector in Asia-Pacific countries will make students more aware of news and information locally and globally, and facilitates communication and collaboration with peers. This study confirmed findings in the current literature (Issa, 2014; Kearns \& Frey, 2010; Kontos et al., 2010; Lanning, Brickhouse, Gunsolley, Ranson, \& Willett, 2011; Vereecken, Van Heddeghem, Colle, Pickavet, \& Demeester, 2010; Waycott, Bennett, Kennedy, Dalgarno, \& Gray, 2010) as the use of SN assists students with both their studies and social life.

Furthermore, the study results confirmed that the individual cultures of Asia-Pacific countries can influence the adoption of SN by HE students in this region. It came to our attention that Bhutan and India students perceived the same advantages - that $\mathrm{SN}$ allows students to have more communication and collaboration with their peers, and encourages them to complete their study tasks independently. On the other hand, Bhutan, India and Malaysia shared a new factor which is communication and collaboration with their peers; while South Korea and Australia shared the new advantage namely, the making of new acquaintances. Students in Australia, Bhutan, India, Malaysia, and Pakistan indicated that SN enables them to study independently. These results confirmed that culture can influence SN adoption; despite students living in different countries, they are living in the same region; therefore, they share the same attitudes and thoughts regarding the use of SN. This outcome answered research question two, and confirmed findings in the current literature (Lowry et al., 2010; Papacharissi, 2010; Wallace \& Brooks, 2015). Finally, we combined the results from all the countries (see Table 4), and SPSS generated two new advantages related to SN use by Asia-Pacific students. These advantages are: study tasks can be facilitated and accomplished quickly; and SN enables students to communicate and collaborate with peers worldwide.

Figures 4, 5,6,7,8, and 9 indicate the new advantages for Australia, Bhutan, India, Malaysia, Pakistan and South Korea regarding SN use among Asia-Pacific students. Each variable and factor loading is assigned a different color.

Furthermore, the researchers investigated whether the use of SN has any disadvantages; by examining the online survey, the SPSS generated two to three disadvantages for some countries (see Table 5). These disadvantages were, namely, depression and gambling, lack of concentration, security and privacy, loneliness, and preventing students from using the traditional media. Furthermore, the SPSS results indicated that students from several countries perceive the same disadvantages: students in Australia, India, Pakistan and South Korea mention depression and depression and anxiety; while the majority of the students in Australia, Bhutan, Pakistan and South Korea are concerned about security and privacy issues associated with SN. Finally, students in India, Malaysia and South Korea believe that SN prevents students from obtaining information via traditional media such as television and newspapers. 
Table 4. Social networking advantages - prepared by researchers

\begin{tabular}{|c|c|}
\hline \multicolumn{2}{|r|}{ Advantages } \\
\hline Country & Label /Advantages \\
\hline Australia & $\begin{array}{l}\text { - Independent study and sustainable person } \\
\text { - Make new acquaintances } \\
\text { - Acquire local and global knowledge and information }\end{array}$ \\
\hline Bhutan & $\begin{array}{l}\text { - Accomplish my study independently } \\
\text { - Communication and collaboration with my peers }\end{array}$ \\
\hline India & $\begin{array}{l}\text { - Independent study } \\
\text { - Communication and collaboration with my peers }\end{array}$ \\
\hline Malaysia & $\begin{array}{l}\text { - Directed study and sustainability } \\
\text { - Communication and collaboration among my peers }\end{array}$ \\
\hline Pakistan & $\begin{array}{l}\text { - Conclude study rapidly } \\
\text { - Awareness and communication locally and globally }\end{array}$ \\
\hline South Korea & $\begin{array}{l}\text { - Tool for study and research } \\
\text { - Cutting edge and awareness locally and globally } \\
\text { - Attain new romance acquaintances }\end{array}$ \\
\hline All the Countries in this study & $\begin{array}{l}\text { - Support and accomplish study swiftly; } \\
\text { - Communicate and collaborate with peers world-wide }\end{array}$ \\
\hline
\end{tabular}

Figure 4. Australia - New advantages - prepared by researchers

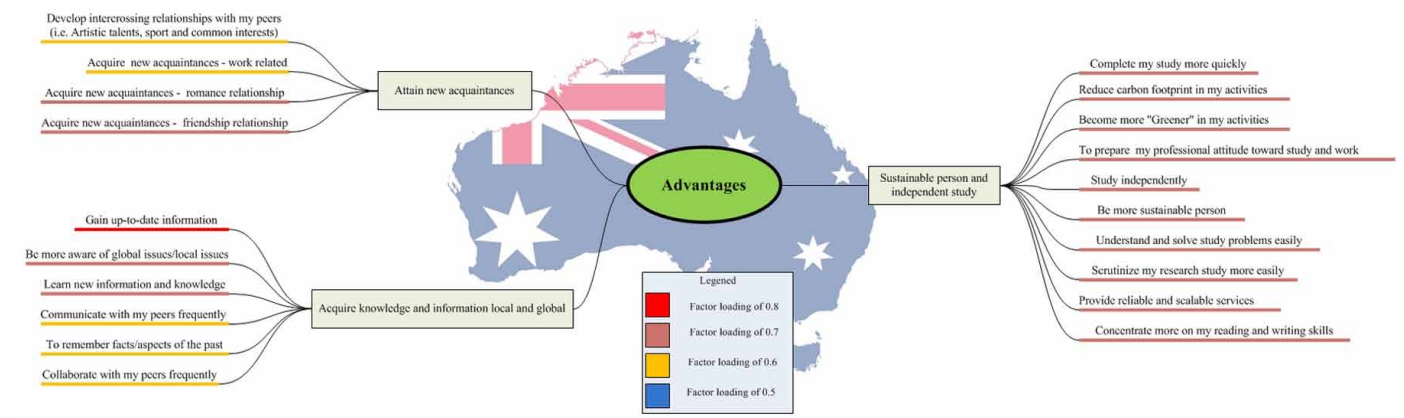

Figure 5. Bhutan - new advantages - prepared by researchers

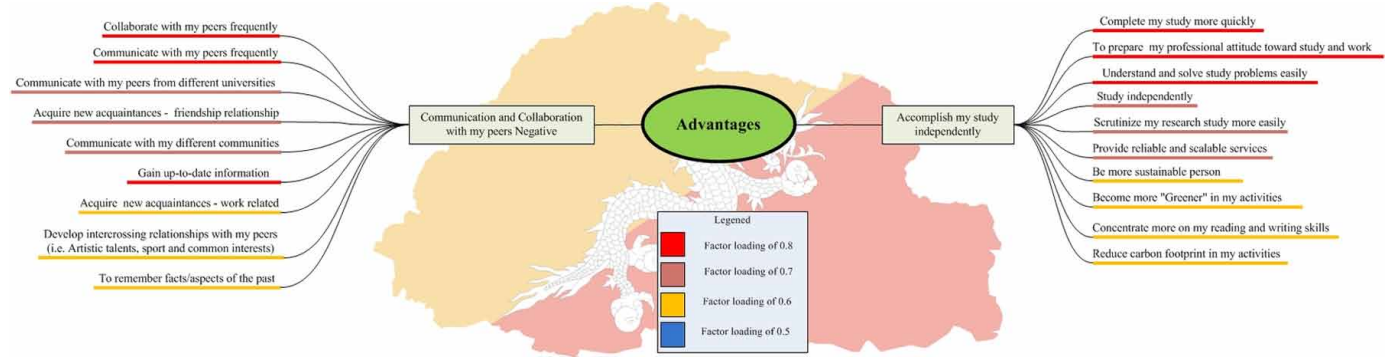




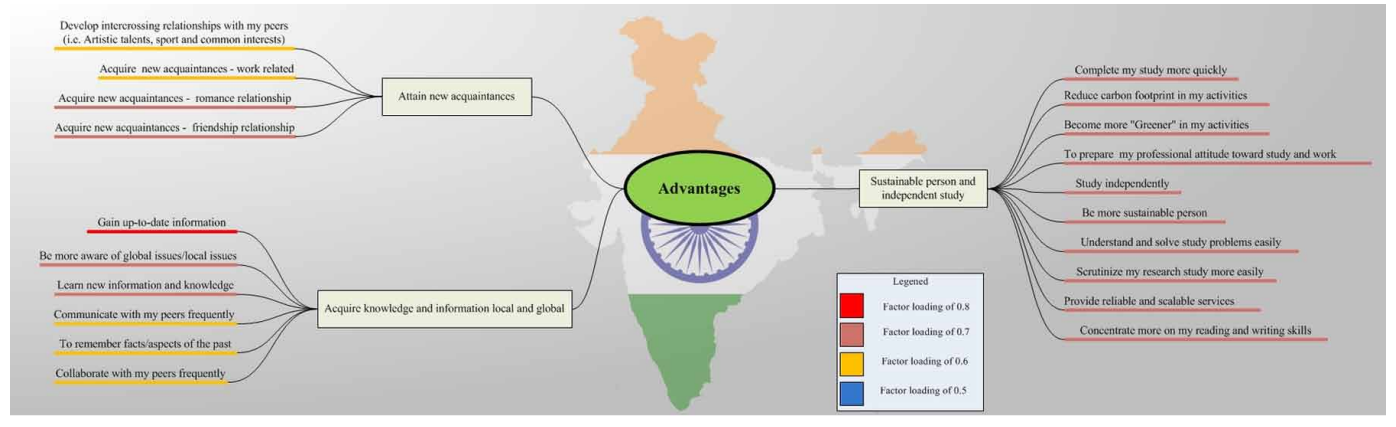

Figure 7. Malaysia - new advantages - prepared by researchers

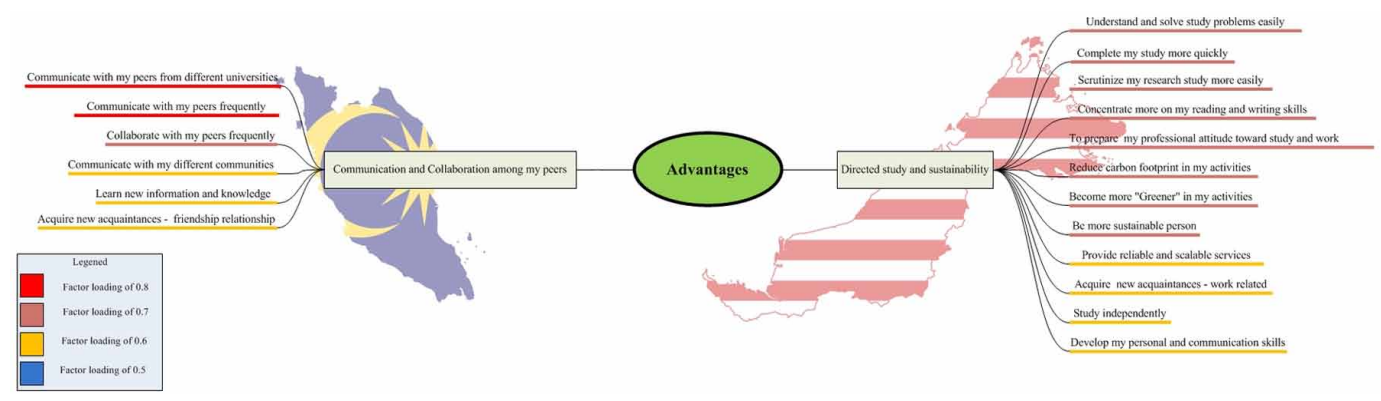

Figure 8. Pakistan - new advantages - prepared by researchers

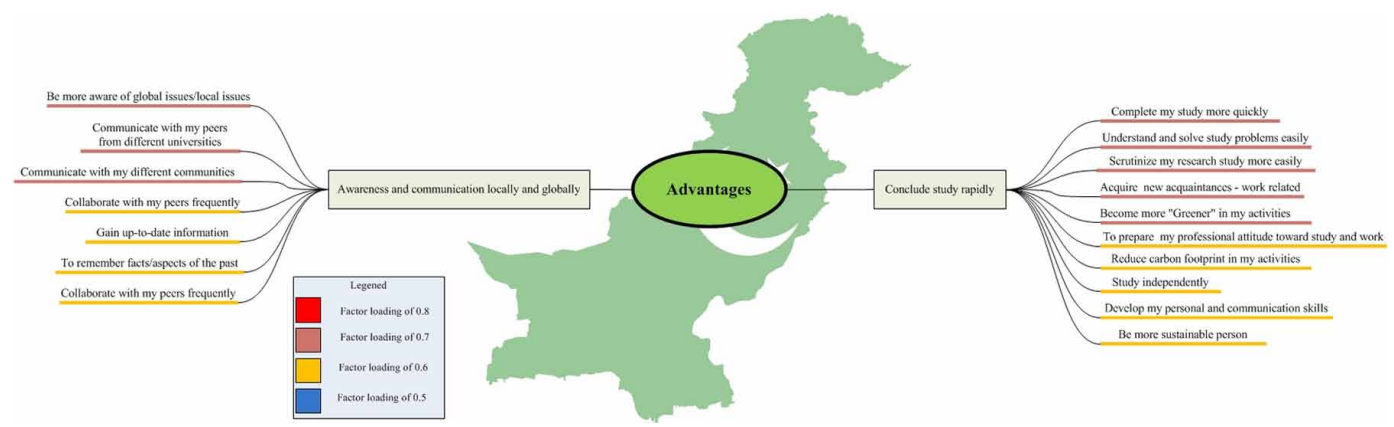

Finally, the online survey data for all countries were combined to examine the new disadvantages that emerged for the six countries. The SPSS generated three disadvantages, namely: depression and loneliness; SN prevents students from engaging in traditional activities, most importantly, they are concerned about security and privacy particularly when sharing personal details with others. First of all, by listing these disadvantages the research questions were answered and confirmed the literature findings (Andrzejczak \& Liu, 2010; Dalbudak, Evren, Aldemir, Coskun, Ugurlu, \& Yildirim, 2013; Fox \& Moreland, 2015; Frison \& Eggermont, 2015; Grabher \& König, 2017; Martínez-Alemán \& Wartman, 2008; Mueller, Mitchell, Peterson, Faber, Steffen, Crosby, \& Claes, 2011; Selfhout, Branje, Delsing, Bogt, \& Meeus, 2009 ; Young \& Rodger, 1998). 
Figure 9. South Korea - new advantages - prepared by researchers

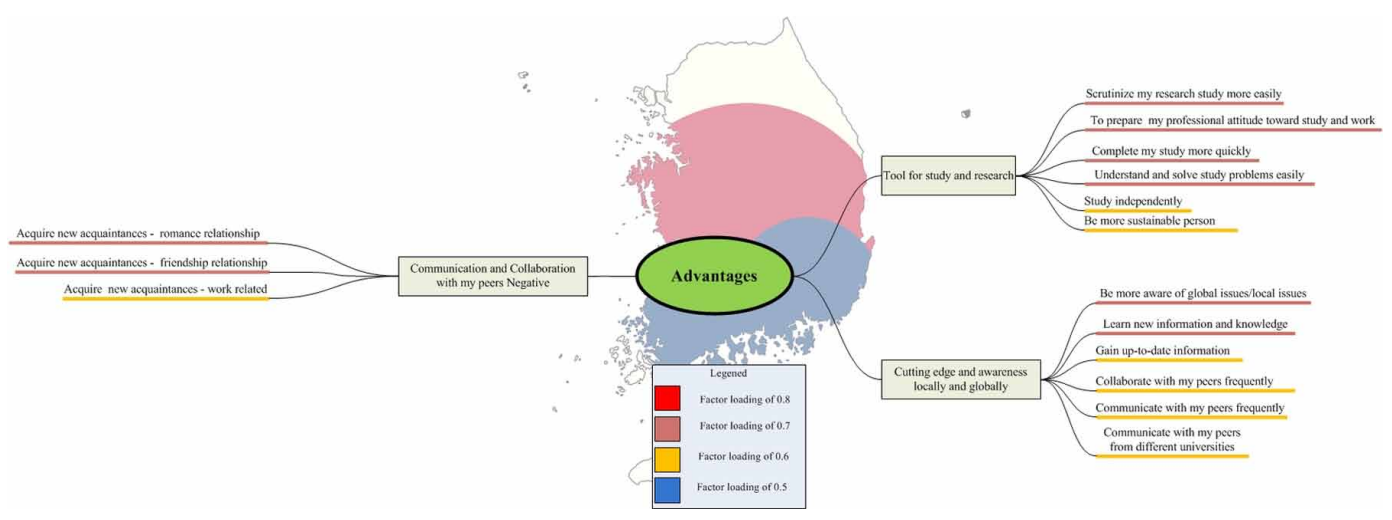

However, these new disadvantages alerted the researchers and academics to the likelihood that students' incorrect or inappropriate use of SN will lead to several problems (see Table 5). Therefore, a suitable and appropriate model should be adopted especially regarding assessment and learning activities of students, to prevent or at least minimize the disadvantages. These problems should be tackled promptly by introducing a new social networking model: Social Networking and Education Model (SNEM) (Issa, Isaias, \& Kommers, 2016). The aim of SNEM is to assist academics and researchers to implement $\mathrm{SN}$ in the education sector successfully by reducing the disadvantages and increasing the benefits associated with SN. The SNEM contains five elements namely: Teaching Methods, Learning, Technology Design and Psychological Aspects.

Table 5. Social networking disadvantages - prepared by researchers

\begin{tabular}{|c|c|}
\hline \multicolumn{2}{|c|}{ Disadvantages } \\
\hline Country & Label /Disadvantages \\
\hline Australia & $\begin{array}{l}\text { - Depression and gambling } \\
\text { - Privacy and Security }\end{array}$ \\
\hline Bhutan & $\begin{array}{l}\text { - Lack of concentration and social activities } \\
\text { - Security and privacy }\end{array}$ \\
\hline India & $\begin{array}{l}\text { - Depression and Loneliness } \\
\text { - Dispersing and Distraction } \\
\text { - Avert using the traditional media }\end{array}$ \\
\hline Malaysia & $\begin{array}{l}\text { - Failing and distraction to study on time } \\
\text { - Prevent using the traditional media }\end{array}$ \\
\hline Pakistan & $\begin{array}{l}\text { - Depression and loneliness } \\
\text { - Lack of concentration } \\
\text { - Security and Privacy }\end{array}$ \\
\hline South Korea & $\begin{array}{l}\text { - Loneliness, depression and anxiety } \\
\text { - Prevent using the traditional media } \\
\text { - Security and privacy }\end{array}$ \\
\hline All the Countries in this study & $\begin{array}{l}\text { - Depression and Loneliness } \\
\text { - Prevent using the traditional activities } \\
\text { - Security and Privacy }\end{array}$ \\
\hline
\end{tabular}


Figures 10, 11, 12, 13, 14, and 15 indicate the new disadvantages for Australia, Bhutan, India, Malaysia, Pakistan and South Korea regarding SN use by Asia-Pacific students. Each variable and factor loading is assigned a different color.

\section{NEW THEORETICAL FINDINGS AND CONTRIBUTION}

This study has made numerous theoretical contributions to the current literature, especially regarding SN awareness and specifically the advantages and disadvantages associated with social networking, specifically in the Asia-Pacific region. Tables 4 and 5 list the advantages and disadvantages for each country and for the All the Countries chosen for this study, respectively. This study will assist researchers to recognize students' attitudes toward SN for study or work especially in AP. SN provides several advantages, but can also produce disadvantages. Therefore, this study confirmed the research aims, as it generated new advantages and disadvantages of SN use among AP students. Consequently, researchers and academics should work very closely locally and globally to minimize the disadvantages and increase the advantages for students world-wide, and especially in the Asia-Pacific region.

Furthermore, this study confirmed that although students are living in different countries, they perceive the same advantages and disadvantages of SN; this means that culture is capable of influencing the adoption of SN by Asia-Pacific students since they are living in the same region and share the same attitudes and mind-set regarding SN adoption in the education sector. Table 6 illustrates the relationship between Hofstede's cultural framework and the use of SN from the perspective of the Asia-Pacific sample obtained for this study.

Figure 10. Australia - new disadvantages - prepared by researchers

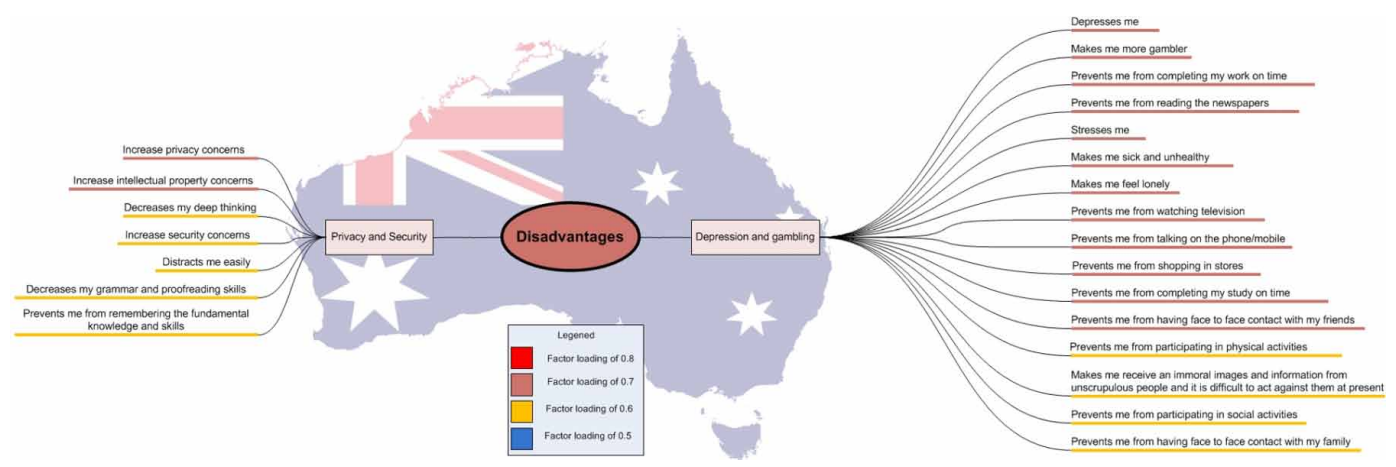

Figure 11. Bhutan - new disadvantages - prepared by researchers

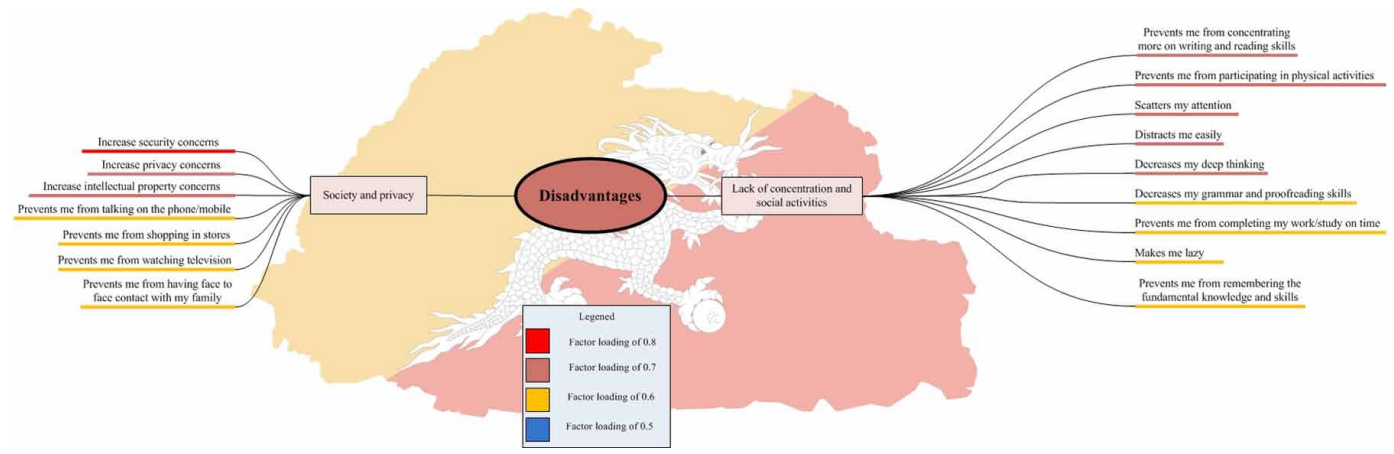


Figure 12. India - new disadvantages - prepared by researchers

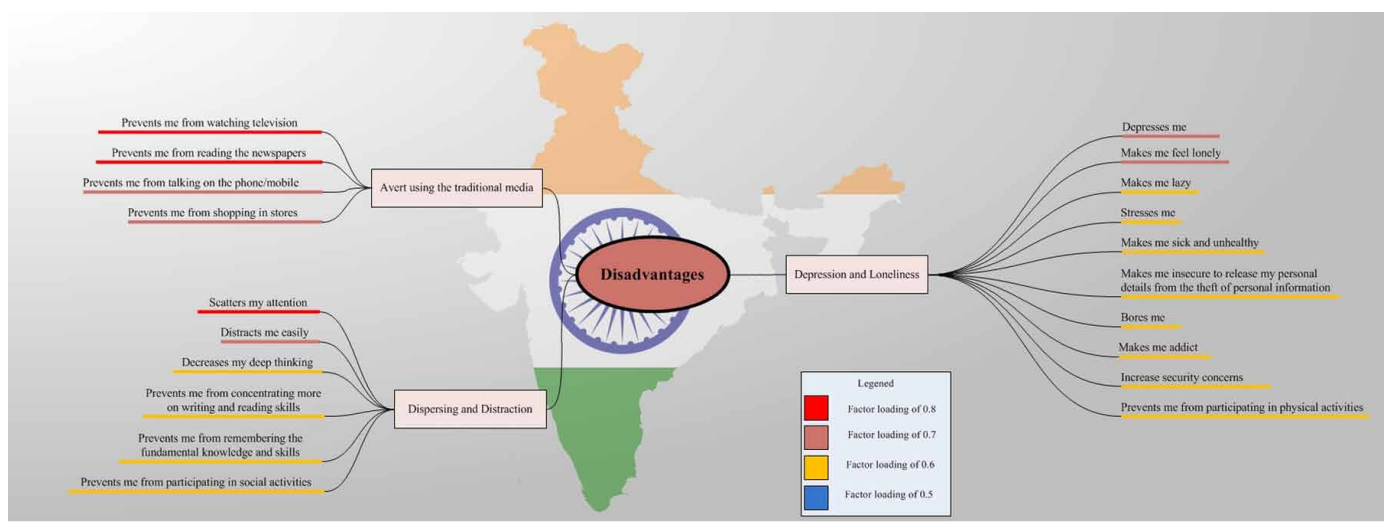

Figure 13. Malaysia - new disadvantages - prepared by researchers

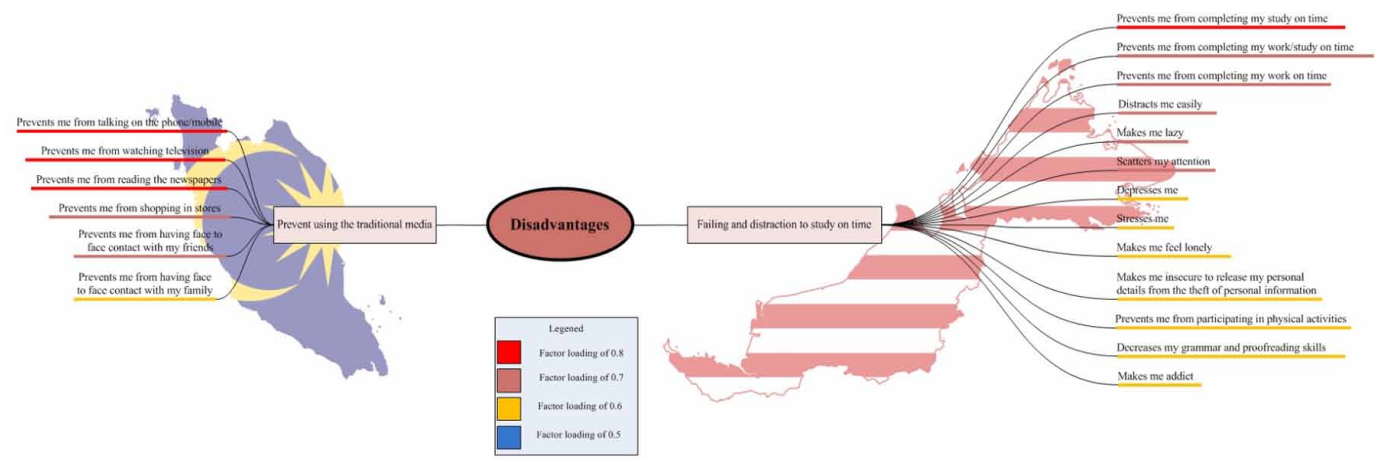

Figure 14. Pakistan- new disadvantages - prepared by researchers

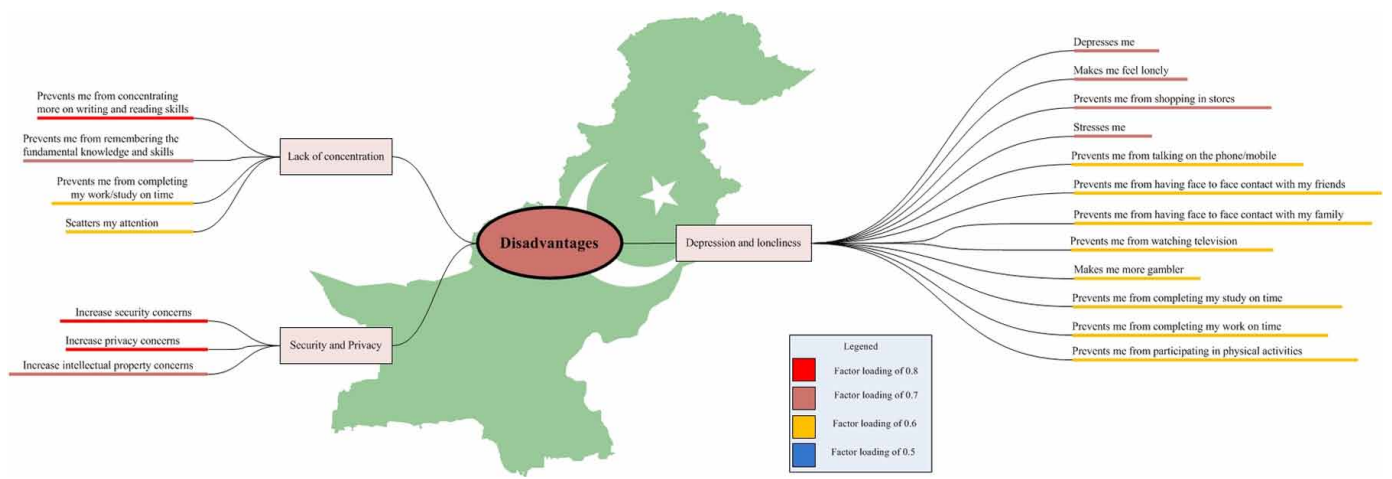

Table 6 lists the advantages and disadvantages perceived by AP students who are using SN in the education sector based on Hofstede's cultural framework. It was noted that students in some AP countries share the same opinion regarding the advantages and disadvantages in terms of Hofstede's cultural framework. However, some advantages and disadvantages are missing from Hofstede's cultural framework, although this issue is outside the scope of this study and will not be addressed. 


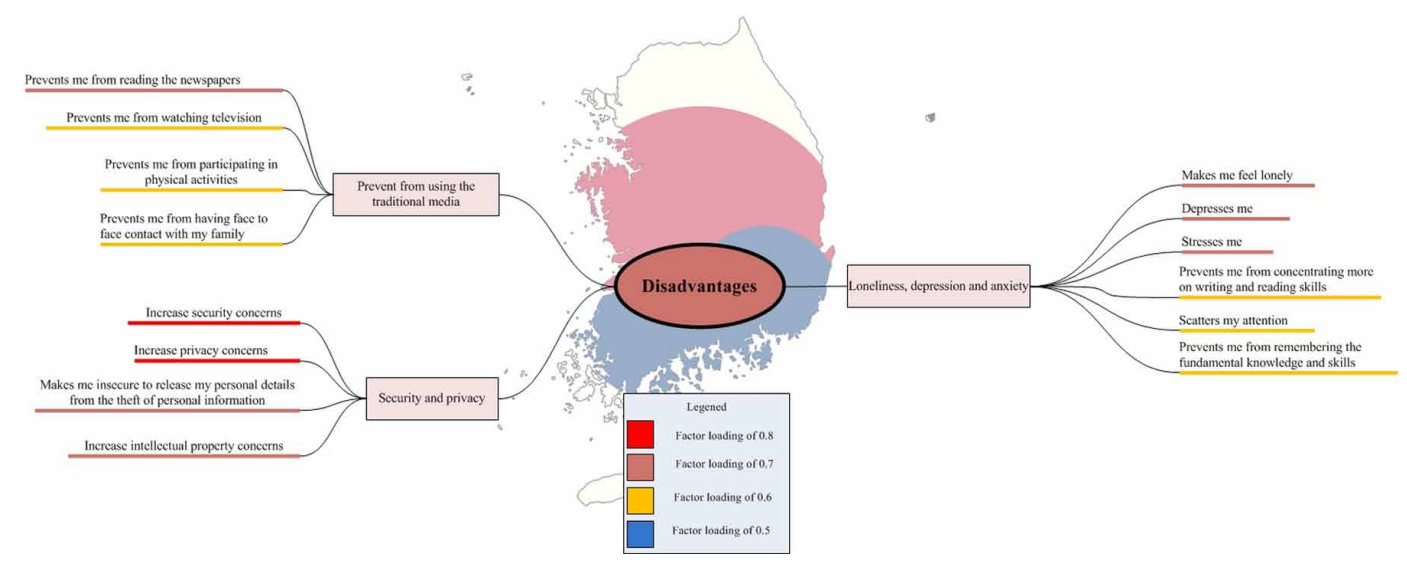

Table 6. Relationship between Hofstede's cultural framework and the use of SN from the Asia-Pacific perspectives

\begin{tabular}{|c|c|c|c|c|c|}
\hline $\begin{array}{l}\text { Hofstede's } \\
\text { Cultural } \\
\text { Framework }\end{array}$ & $\begin{array}{l}\text { AP Countries } \\
\text { Comparison } \\
\text { (Figure 5) }\end{array}$ & SN Advantages & $\begin{array}{l}\text { AP Country } \\
\text { Based on this } \\
\text { Study }\end{array}$ & $\begin{array}{c}\text { SN } \\
\text { Disadvantages }\end{array}$ & $\begin{array}{c}\text { AP Country } \\
\text { Based on this } \\
\text { Study }\end{array}$ \\
\hline Power Distance & & N/A & N/A & N/A & N/A \\
\hline Individualism & Australia & $\begin{array}{l}\text { Independent } \\
\text { study }\end{array}$ & $\begin{array}{l}\text { Australia } \\
\text { Bhutan } \\
\text { India } \\
\text { Malaysia }\end{array}$ & N/A & N/A \\
\hline Collectivism & $\begin{array}{l}\text { South Korea } \\
\text { Pakistan } \\
\text { Malaysia }\end{array}$ & $\begin{array}{l}\text { Communication } \\
\text { and collaboration } \\
\text { with my peers }\end{array}$ & $\begin{array}{l}\text { Bhutan } \\
\text { India } \\
\text { Malaysia }\end{array}$ & & N/A \\
\hline Masculine & $\begin{array}{l}\text { Australia } \\
\text { India } \\
\text { Malaysia } \\
\text { Pakistan }\end{array}$ & N/A & N/A & N/A & N/A \\
\hline Femininity & $\begin{array}{l}\text { South Korea } \\
\text { Bhutan }\end{array}$ & Sustainability & $\begin{array}{l}\text { Australia } \\
\text { Malaysia }\end{array}$ & N/A & N/A \\
\hline $\begin{array}{l}\text { Uncertainty } \\
\text { avoidance }\end{array}$ & $\begin{array}{l}\text { Pakistan } \\
\text { South Korea }\end{array}$ & $\begin{array}{l}\text { Cutting edge and } \\
\text { awareness locally } \\
\text { and globally }\end{array}$ & $\begin{array}{l}\text { Australia } \\
\text { Pakistan } \\
\text { South Korea }\end{array}$ & Security & $\begin{array}{l}\text { Australia } \\
\text { Bhutan } \\
\text { Pakistan } \\
\text { South Korea }\end{array}$ \\
\hline $\begin{array}{l}\text { Long Term } \\
\text { Orientation }\end{array}$ & South Korea & $\begin{array}{l}\text { Tool for study } \\
\text { and research }\end{array}$ & South Korea & $\begin{array}{l}\text { Loneliness, } \\
\text { depression and } \\
\text { anxiety }\end{array}$ & $\begin{array}{l}\text { Australia } \\
\text { India } \\
\text { Pakistan } \\
\text { South Korea }\end{array}$ \\
\hline Indulgence & Australia & $\begin{array}{l}\text { Make new } \\
\text { acquaintances }\end{array}$ & $\begin{array}{l}\text { Australia } \\
\text { South Korea }\end{array}$ & N/A & N/A \\
\hline Restraint & $\begin{array}{l}\text { India } \\
\text { South Korea }\end{array}$ & & & $\begin{array}{l}\text { Prevents use of } \\
\text { traditional media }\end{array}$ & $\begin{array}{l}\text { India } \\
\text { Malaysia } \\
\text { South Korea }\end{array}$ \\
\hline
\end{tabular}


This study confirmed the cultural contexts based on Hofstede's cultural framework. However, some countries shift from one dimension to another (the new countries are in italics). For example, regarding the Individualism dimension, in Bhutan, India and Malaysia, students in the higher education sector prefer to study independently by using SN technology. As indicated in Figure 5, these countries have a more collectivist culture. For example, from this study, Australia and Malaysia are part of the Femininity dimension, since Australian and Malaysian students are using SN tool as a tool fostering sustainability, since they are concerned about sustainability and our natural resources similar to South Korea and Bhutan as depicted in Figure 5.

In regard to the Uncertainty Avoidance dimension, according to this study, Australia is added to this dimension, as the Australian participants are keen to know about cutting edge technology and awareness locally and globally. AP students in Australia, Bhutan, North Korea and Pakistan regard the issue of security as a disadvantage. As for the Long Term Orientation dimension, South Korea is keen to use modern education methods to enhance the teaching and learning for the future. South Korean participants confirmed that the use of SN in the education sector was beneficial for study and research. However, for the same dimension, South Korean, Australian, Indian and Pakistani students believed that the use of SN can lead to loneliness, depression and anxiety. As for the Indulgence dimension, Australian students are using SN to make new acquaintances, and this is one of the advantages also perceived by the South Korean students. Finally, the Restraint dimension indicated that the use of SN technology prevented students from India, South Korea and Malaysia (a new country added to this dimension) from using traditional media.

This study confirmed that culture influences the use of SN in AP countries, as students from various AP countries have the same opinion about the SN advantages and disadvantages. Moreover, the new findings from this study match AP countries comparison based on Hofstede's cultural framework; while some AP countries are added to different dimensions in the Hofstede's cultural framework based on students' attitudes toward SN use, this means, this study added new findings and significance to the current literature.

As mentioned previously, the researchers examined the Asia-Pacific results as a whole. Figures 16 and 17 show the advantages and disadvantages for all the Asia-Pacific countries used for this study; the cylindrical shape indicates a factor loading of .8, the plague shape shows a .7 factor loading and the rectangle shape indicates a .6 factor loading.

Finally, this study raised the awareness of the advantages and disadvantages of the use of $\mathrm{SN}$ in the Asia-Pacific education sector as the new generation world-wide considers this as an essential tool that enables students to improve their personal and professional skills, which are needed for their current studies and the workforce in future. Therefore, researchers and academics should take the lead in encouraging teaching and learning departments in education sector institutions to integrate SN principles in the curriculum, pedagogy and teaching principles, especially in the assessments and learning/teaching activities by implementing the SNEM model in the integration in order to increase the advantages and reduce or eliminate the disadvantages of SN use by Asia-Pacific students.

\section{LIMITATIONS}

This study's investigation was limited to six countries in the Asia-Pacific region and was intended to determine students' attitudes to SN. The results obtained from the 826 valid responses generated new advantages and disadvantages from the Asia-Pacific students' perspective. Moreover, the relation between learning styles and the social networking use were not analyzed in this study. Therefore, further research will be carried out in the future to examine the SN use in other Asia-Pacific countries to collect further data to strengthen the goals research conclusions. 
Figure 16. Asia-Pacific countries chosen for this study - advantages - prepared by researchers

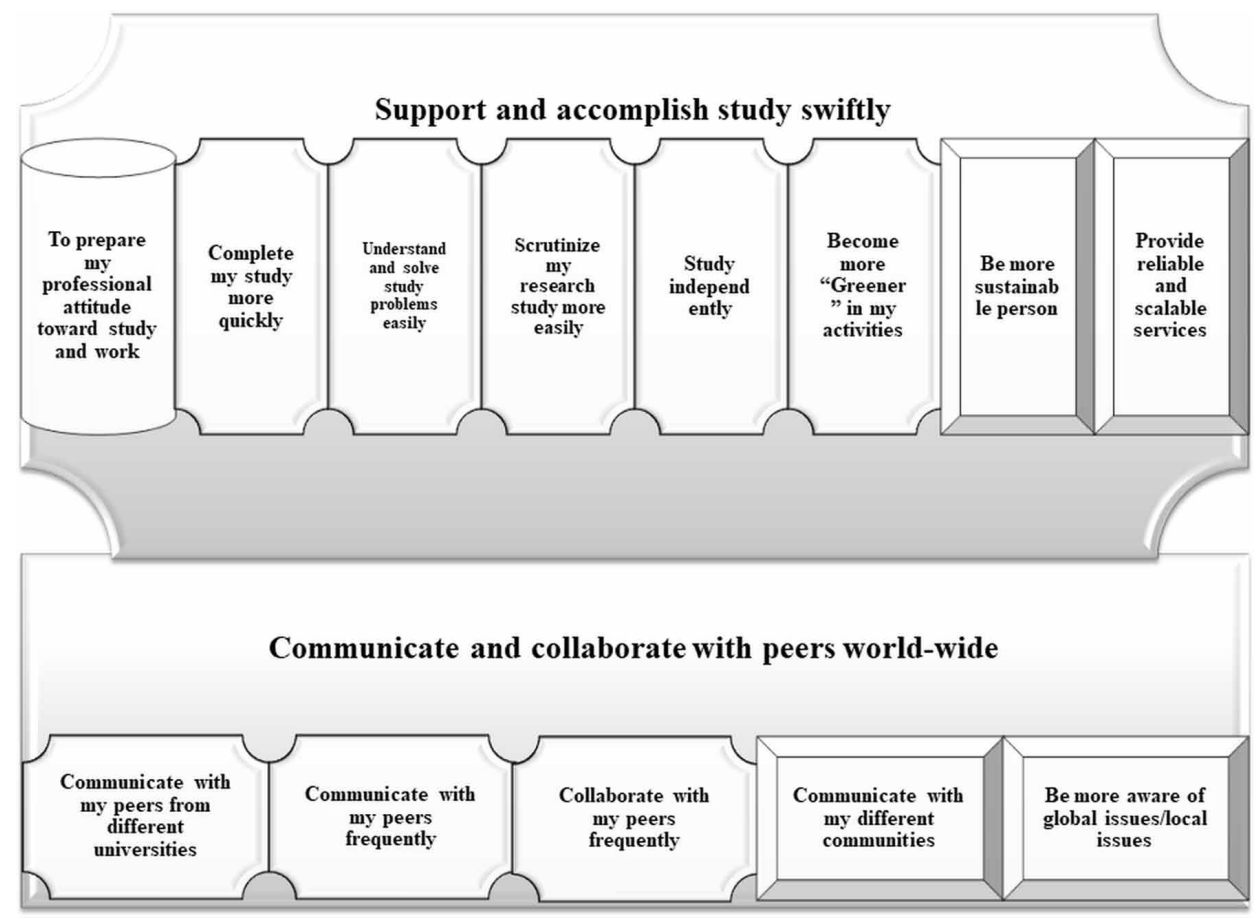

Figure 17. Asia-Pacific countries chosen for this study - disadvantages - prepared by researchers

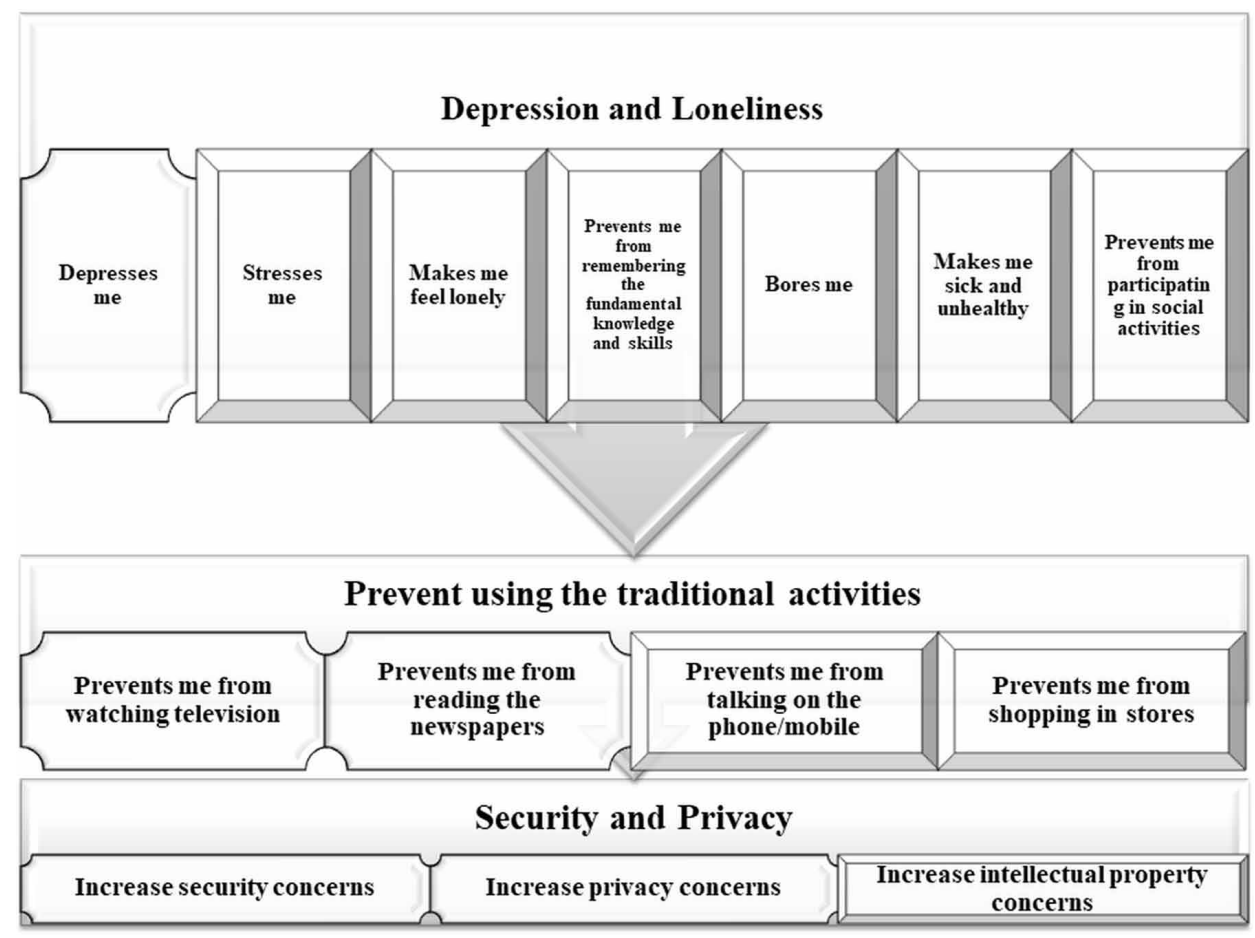




\section{CONCLUSION}

This study examined the Asia-Pacific students' attitudes and behaviours regarding the use of SN in their studies, and whether their culture influences their use of SN. A total of 826 students were recruited for this study from six countries in the Asia-Pacific region, namely Australia, Bhutan, India, Malaysia, Pakistan, and South Korea; the data was collected over 6 to 8 months. The online survey outcomes indicated several advantages and disadvantages associated with SN use by Asia-Pacific students. Namely, it encouraged more communication and collaboration with peers, made them more sustainable; enabled them to acquire local and global knowledge and information; enabled them to establish new romantic attachments, and SN helped them to finish their study tasks quickly. On the other hand, there were several disadvantages including depression and gambling, privacy and security concerns, loneliness, and less utilization of traditional media such as TV and newspapers. These disadvantages sent a warning to researchers and academics to tackle these problems by implementing an appropriate model such as SNEM to minimise the disadvantages and extend the advantages. Moreover, this study confirmed that culture had an influence on SN adoption, since students in different Asia-Pacific countries perceived the same advantages and disadvantages concerning SN use, since they are living in the same region and have the same attitudes and behaviours. Furthermore, some AP countries are added to different dimensions in the Hofstede's cultural framework based on students' attitudes toward SN use, this means, this study added new findings and significance to the current literature. Finally, further research will be carried out in the future to examine SN use in other Asia-Pacific countries to collect further data to consolidate the research outcomes and objectives. 


\section{REFERENCES}

Abdulahi, A., Samadi, B., \& Gharleghi, B. (2014). A study on the negative effects of social networking sites such as Facebook among Asia Pacific University scholars in Malaysia. International Journal of Business and Social Science, 5(10).

Andrzejczak, C., \& Liu, D. (2010). The effect of testing location on usability testing performance, participant stress levels, and subjective testing experience. Journal of Systems and Software, 83(7), 1258-1266. doi:10.1016/j. jss.2010.01.052

Bland, J., \& Altman, D. G. (1997). Statistics notes: Cronbach's alpha. BMJ (Clinical Research Ed.), 314(7080), 572. doi:10.1136/bmj.314.7080.572 PMID:9055718

Blatt, A. J. (2015). Collaborative Mapping. In Health, Science, and Place (pp. 63-75). Springer.

Bravo, G., \& Potvin, L. (1991). Estimating the reliability of continuous measures with Cronbach's alpha or the intraclass correlation coefficient: Toward the integration of two traditions. Journal of Clinical Epidemiology, 44(4-5), 381-390. doi:10.1016/0895-4356(91)90076-L PMID:2010781

Burns, R., \& Burns, R. (2008). Business Research Methods and Statistics Using SPSS. Sage (Atlanta, Ga.).

Chugh, R., \& Ruhi, U. (2018). Social media in higher education: A literature review of Facebook. Education and Information Technologies, 23(2), 605-616. doi:10.1007/s10639-017-9621-2

Clark, A. (2010). How to create change in a conservative culture. Green Economy. Retrieved from http:// greeneconomypost.com/how-to-create-green-change-in-a-conservative-culture-9086.htm

Clarke, M. (2010). Controlling privacy on social networking services. UXmatters. Retrieved from http://www. uxmatters.com/mt/archives/2010/04/controlling-privacy-on-social-networking-services.php

Connelly, L. M. (2011). Cronbach’s Alpha. Medsurg Nursing, 20(1), 44-45. PMID:21446295

Costello, A., \& Osborne, J. (2005). Best practices in exploratory factor analysis: Four recommendations for getting the most from your analysis. Practical Assessment, Research \& Evaluation, 10(7), 1-9.

Couper, M. P., Traugott, M. W., \& Lamias, M. J. (2001). Web survey design and administration. Public Opinion Quarterly, 65(2), 230-253. doi:10.1086/322199 PMID:11420757

Dalbudak, E., Evren, C., Aldemir, S., Coskun, K. S., Ugurlu, H., \& Yildirim, F. G. (2013). Relationship of internet addiction severity with depression, anxiety, and alexithymia, temperament and character in university students. Cyberpsychology, Behavior, and Social Networking, 16(4), 272-278. doi:10.1089/cyber.2012.0390 PMID:23363230

Das, J. R., Dash, M., Sahoo, M. A., \& Mohanty, A. K. (2017). An empirical study on customers' internet banking behavior. International Journal of Management, 7(7). Retrieved from http://www.ijmra.us

De-Marcos, L., Domínguez, A., Saenz-de-Navarrete, J., \& Pagés, C. (2014). An empirical study comparing gamification and social networking on e-learning. Computers \& Education, 75, 82-91. doi:10.1016/j. compedu.2014.01.012

DeKay, S. (2009). Are business-oriented social networking web sites useful resources for locating passive jobseekers? Results of a recent study. Business Communication Quarterly, 72(1), 101-105. doi: $10.1177 / 1080569908330378$

Dillenbourg, P. (1999). What do you mean by collaborative learning? Oxford: Elsevier.

Dillman, D. A. (2007). Mail and Internet Surveys "The Tailored Design Method" (2nd ed.). USA: John Wiley $\&$ Sons, Inc.

Dillman, D. A., Phelps, G., Tortora, R., Swift, K., Kohrell, J., Berck, J., \& Messer, B. L. (2009). Response rate and measurement differences in mixed-mode surveys using mail, telephone, interactive voice reponse (IVR) and the Internet. Social Science Research, 38(1), 1-18. doi:10.1016/j.ssresearch.2008.03.007

Dillman, D. A., Reipus, U. D., \& Matzat, U. (2010). Advice in Surveying the general public over the Internet. International Journal of Internet Science, 5(1), 1-4. 
Dillman, D. A. (2017). The promise and challenge of pushing respondents to the Web in mixed-mode surveys. Survey Methodology, 43 (1).

Din, N., Yahya, S., Suzan, R., \& Kassim, R. (2012). Online Social Networking for Quality of Life. Procedia: Social and Behavioral Sciences, 35, 713-718. doi:10.1016/j.sbspro.2012.02.141

Durak, G. (2017). Using Social Learning Networks (SLNs) in higher education: Edmodo through the lenses of academics. The International Review of Research in Open and Distributed Learning, 18(1). doi:10.19173/ irrodl.v18i1.2623

Dziuban, C. D., \& Shirkey, E. C. (1974). When is a correlation matrix appropriate for factor analysis? Some decision rules. Psychological Bulletin, 81(6), 358-361. doi:10.1037/h0036316

Fan, W., \& Yan, Z. (2010). Factors affecting response rates of the web survey: A systematic review. Computers in Human Behavior, 26(2), 132-139. doi:10.1016/j.chb.2009.10.015

Forrester Research. (2010). Social Networking in The Enterprise: Benefits and Inhibitors. USA: Forrester Research.

Fox, J., \& Moreland, J. J. (2015). The dark side of social networking sites: An exploration of the relational and psychological stressors associated with Facebook use and affordances. Computers in Human Behavior, 45(0), 168-176. doi:10.1016/j.chb.2014.11.083

Frison, E., \& Eggermont, S. (2015). The impact of daily stress on adolescents' depressed mood: The role of social support seeking through Facebook. Computers in Human Behavior, 44(0), 315-325. doi:10.1016/j. chb.2014.11.070

Frohlich, M. T., \& Westbrook, R. (2001). Arcs of integration: An international study of supply chain strategies. Journal of Operations Management, 19(2), 185-200. doi:10.1016/S0272-6963(00)00055-3

Frydenberg, M. (2008). Wikis as a Tool for Collaborative Course Management. MERLOT Journal of Online Learning and Teaching, 4(2), 169-181.

Gliem, J. A., \& Gliem, R. R. (2003). Calculating, Interpreting, and Reporting Cronbach's Alpha Reliability Coefficient for Likert-Type Scales. Paper presented at the 2003 Midwest Research to Practice Conference in Adult, Continuing and COmmunity Education.

Grabher, G., \& König, J. (2017). Performing network theory? Reflexive relationship management on social network sites. In Networked Governance (pp. 121-140). Springer.

Gülbahar, Y., Rapp, C., Kilis, S., \& Sitnikova, A. (2017). Enriching higher education with social media: Development and evaluation of a social media toolkit. The International Review of Research in Open and Distributed Learning, 18(1). doi:10.19173/irrodl.v18i1.2656

Baird, H. (2011). From social media to social customer relationship management. Strategy and Leadership, 39(5), 30-37. doi:10.1108/10878571111161507

Heydari, A., \& Laroche, M. (2017). Cross-Cultural Study of Social Media-Based Brand Communities: An Abstract. Paper presented at the Academy of Marketing Science Annual Conference.

Hill, B. D. (2012). Sequential Kaiser-Meyer-Olkin Procedure As an Alternative for Determining The Number of Factors in Common-Factor Analysis: A Monte Carlo Simulation [Doctoral dissertation]. Oklahoma State University.

Hofstede, G. (1984). Culture's consequences: International differences in work-related values. sage.

Hofstede, G. (2003). Culture's consequences: Comparing values, behaviors, institutions and organizations across nations. Sage Publications.

Hofstede Insights. (2018). Country comparison. Retrieved from https://www.hofstede-insights.com/countrycomparison/pakistan,south-korea/

Holmes, K. M., \& O'loughlin, N. (2014). The experiences of people with learning disabilities on social networking sites. British Journal of Learning Disabilities, 42(1), 1-5. doi:10.1111/bld.12001 
Hudson, S., Huang, L., Roth, M. S., \& Madden, T. J. (2016). The influence of social media interactions on consumer-brand relationships: A three-country study of brand perceptions and marketing behaviors. International Journal of Research in Marketing, 33(1), 27-41. doi:10.1016/j.ijresmar.2015.06.004

Issa, T. (2014). Learning, Communication and Interaction via Wiki: An Australian Perspective. In H. Kaur \& X. Tao (Eds.), ICTs and the Millennium Development Goals: A United Nations Perspective (pp. 1-17). Boston, MA: Springer US. doi:10.1007/978-1-4899-7439-6_1

Issa, T. (2016). Social Networking in Australia: Opportunities and Risks. In T. Issa, P. Isaias, \& P. Kommers (Eds.), Social Networking and Education Global Perspectives (pp. 17-39). USA: Springer. doi:10.1007/9783-319-17716-8_2

Issa, T., Isaias, P., \& Kommers, P. (2016). Social Networking and Education Model (SNEM). In T. Issa, P. Isaias, \& P. Kommers (Eds.), Social Networking and Education Global Perspectives (pp. 323-345). USA: Springer. doi:10.1007/978-3-319-17716-8_20

Johnson, B. K., \& Knobloch-Westerwick, S. (2014). Glancing up or down: Mood management and selective social comparisons on social networking sites. Computers in Human Behavior, 41(0), 33-39. doi:10.1016/j. chb.2014.09.009

Kearns, L., \& Frey, B. (2010). Web 2.0 Technologies and Back Channel Communication in an Online Learning Community. TechTrends, 54(3), 41-54.

Kelin, K. (2008). Are Social Networking Sites Useful for Business? Bloomberg. Retrieved from http://www. bloomberg.com/bw/stories/2008-08-06/are-social-networking-sites-useful-for-business-businessweek-businessnews-stock-market-and-financial-advice

Kepios. (2017). Digital in Asia-Pacific in 2017 Retrieved from https://kepios.com/blog/apac2017

Kiehne, T. (2004). Social Networking Systems: History, Critique, and Knowledge Management Potentials Retrieved from https://www.ischool.utexas.edu/ i385q/archive/kiehne_t/kiehne\%282004\%29-sns.pdf

Kontos, E., Emmons, K., Puleo, E., \& Viswanath, K. (2010). Communication Inequalities and Public Health Implications of Adult Social Networking Site Use in the United States. Journal of Health Communication, 15(S3), 216-235. doi:10.1080/10810730.2010.522689 PMID:21154095

Ku, H.-Y., Tseng, H. W., \& Akarasriworn, C. (2013). Collaboration factors, teamwork satisfaction, and student attitudes toward online collaborative learning. Computers in Human Behavior, 29(3), 922-929. doi:10.1016/j. chb.2012.12.019

Kuzma, Joanne. (2010). Asian government usage of Web 2.0 social media. European Journal of ePractice(9), 1-13.

Langheinrich, M., \& Karjoth, G. (2010). Social networking and the risk to companies and institutions. Information Security Technical Report, 15(2), 51-56. doi:10.1016/j.istr.2010.09.001

Lanning, S. K., Brickhouse, T. H., Gunsolley, J. C., Ranson, S. L., \& Willett, R. M. (2011). Communication Skills Instruction: An Analysis of self, peer-group, student instructors and faculty assessment. Patient Education and Counseling, 83(2), 145-151. doi:10.1016/j.pec.2010.06.024 PMID:20638816

Likert, R. (1932). A Technique for the Measurement of attitudes. Archives de Psychologie, 22(140), 55.

Lin, K. Y., \& Lu, H. P. (2011). Why people use social networking sites: An empirical study integrating network externalities and motivation theory. Computers in Human Behavior, 27(3), 1152-1161. doi:10.1016/j. chb.2010.12.009

Lipp, A., Davis, R. E., Peter, R., \& Davies, J. S. (2014). The use of social media among health care professionals within an online postgraduate diabetes diploma course. Practical Diabetes, 31(1), 14-17a. doi:10.1002/pdi.1821

Lowry, P. B., Zhang, D., Zhou, L., \& Fu, X. (2010). Effects of culture, social presence, and group composition on trust in technology-supported decision-making groups. Information Systems Journal, 20(3), $297-315$. doi:10.1111/j.1365-2575.2009.00334.x

Martínez-Alemán, A. M., \& Wartman, K. L. (2008). Online social networking on campus: Understanding what matters in student culture. Routledge. 
Mathew, B. (2014). Using a social networking tool for blended learning in staff training: Sharing experience from practice. Journal of Neonatal Nursing, 20(3), 90-94. doi:10.1016/j.jnn.2014.03.005

Matusitz, J., \& Musambira, G. (2013). Power distance, uncertainty avoidance, and technology: Analyzing Hofstede's dimensions and human development indicators. Journal of Technology in Human Services, 31(1), 42-60. doi:10.1080/15228835.2012.738561

McCarroll, N., \& Curran, K. (2013). Social Networking in Education. International Journal of Innovation in the Digital Economy, 4(1), 1-15.

McKenna, B. (2010). Social networking: The 'what not to do' guide for organisations. Infosecurity, 7(5), 22-24. doi:10.1016/S1754-4548(10)70086-3

Miller, R., \& Lammas, N. (2010). Social media and its implications for viral marketing. Asia Pacific Public Relations Journal, 11(1), 1-9.

Minocha, S., \& Thomas, P. (2007). Collaborative Learning in a Wiki Environment: Experiences from a Software Engineering Course. New Review of Hypermedia and Multimedia, 13(2), 187-209. doi:10.1080/13614560701712667

Moreno, M. A., \& Kolb, J. (2012). Social Networking Sites and Adolescent Health. Pediatric Clinics of North America, 59(3), 601-612. doi:10.1016/j.pcl.2012.03.023 PMID:22643167

Mueller, A., Mitchell, J. E., Peterson, L. A., Faber, R. J., Steffen, K. J., Crosby, R. D., \& Claes, L. (2011). Depression, materialism, and excessive Internet use in relation to compulsive buying. Comprehensive Psychiatry, 52(4), 420-424. doi:10.1016/j.comppsych.2010.09.001 PMID:21683178

Ngai, E. W., Tao, S. S., \& Moon, K. K. (2015). Social media research: Theories, constructs, and conceptual frameworks. International Journal of Information Management, 35(1), 33-44.

Oh, H. J., Ozkaya, E., \& LaRose, R. (2014). How does online social networking enhance life satisfaction? The relationships among online supportive interaction, affect, perceived social support, sense of community, and life satisfaction. Computers in Human Behavior, 30(0), 69-78. doi:10.1016/j.chb.2013.07.053

Pan, Y., Xu, Y., Wang, X., Zhang, C., Ling, H., \& Lin, J. (2015). Integrating social networking support for dyadic knowledge exchange: A study in a virtual community of practice. Information \& Management, 52(1), 61-70. doi:10.1016/j.im.2014.10.001

Papacharissi, Z. (2010). A networked self: Identity, community, and culture on social network sites. Routledge.

Park, N., Kee, K. F., \& Valenzuela, S. (2009). Being immersed in social networking environment: Facebook groups, uses and gratifications, and social outcomes. Cyberpsychology \& Behavior, 12(6), 729-733. doi:10.1089/ cpb.2009.0003 PMID:19619037

Peluchette, J., \& Karl, K. (2008). Social networking profiles: An examination of student attitudes regarding use and appropriateness of content. Cyberpsychology \& Behavior, 11(1), 95-97. doi:10.1089/cpb.2007.9927 PMID: 18275320

Pempek, T., Yermolayeva, Y., \& Calvert, S. (2000). College Students' social networking experieences on Facebook. Journal of Applied Developmental Psychology.

Peng, M. W., \& Zhou, J. Q. (2005). How network strategies and institutional transitions evolve in Asia. Asia Pacific Journal of Management, 22(4), 321-336. doi:10.1007/s10490-005-4113-0

Peruta, A., \& Shields, A. B. (2017). Social media in higher education: Understanding how colleges and universities use Facebook. Journal of Marketing for Higher Education, 27(1), 131-143. doi:10.1080/08841241 .2016.1212451

Phua, J., \& Jin, S.-A. A. (2011). 'Finding a home away from home': The use of social networking sites by AsiaPacific students in the United States for bridging and bonding social capital. Asian Journal of Communication, 21(5), 504-519. doi:10.1080/01292986.2011.587015

Schaefer, H. S., Larson, C. L., Davidson, R. J., \& Coan, J. A. (2014). Brain, body, and cognition: Neural, physiological and self-report correlates of phobic and normative fear. Biological Psychology, 98, 59-69. doi:10.1016/j.biopsycho.2013.12.011 PMID:24561099 
Sekaran, U. (2003). Research Methods for Business "A Skill Building Approach" (4th ed.). MA, USA: John Wiley \& Sons.

Selfhout, M., Branje, S., Delsing, M., Bogt, T., \& Meeus, W. (2009). Different types of Internet use, depression, and social anxiety: The role of perceived friendship quality. Journal of Adolescence, 32(4), 819-833. doi:10.1016/j. adolescence.2008.10.011 PMID:19027940

Shin, J. C., \& Harman, G. (2009). New challenges for higher education: Global and Asia-Pacific perspectives. Asia Pacific Education Review, 10(1), 1-13. doi:10.1007/s12564-009-9011-6

Sigman, A. (2009). Well connected. Biologist (Columbus, Ohio), 56(1), 14-20.

Smyth, J. D., Dillman, D. A., Christian, L. M., \& O'Neill, A. C. (2010). Using the internet to survey small towns and communities: Limitations and Possibilities in the early 21st Century. The American Behavioral Scientist, 53(9), 1423-1448. doi:10.1177/0002764210361695

Sohmee, J., \& Oppeniander, J. E. (2010). JMP Means Business Statistical Models for Management. USA: SAS Institute Inc.

Steinfield, C., DiMicco, J., Ellison, N., \& Lampe, C. (2009). Bowling Online: Social Networking and Social Capital Within the Organization. Paper presented at the $C \& T$ '09, University Park, Pennsylvania, USA.

Stevens, J. P. (1992). Applied multivariate statistics for the social sciences. Hillsdale, NJ: Erlbaum.

Stump, R. L., \& Gong, W. (2017). Social networking sites: An exploration of the effect of national cultural dimensions on country adoption rates and usage patterns. International Journal of Electronic Business, 13(2-3), 117-142. doi:10.1504/IJEB.2017.083288

Tariq, W., Mehboob, M., Khan, M. A., \& Ullah, F. (2012). The Impact of social media and social networks on education and students of Pakistan. International Journal of Computer Science Issues, 9(4), 407.

Tavakol, M., \& Dennick, R. (2011). Making sense of Cronbach's alpha. International Journal of Medical Education, 2, 53-55. doi:10.5116/ijme.4dfb.8dfd PMID:28029643

Tharp, T. L. (2010). "Wiki, Wiki, Wiki-What?” Assessing Online Collaborative Writing. English Journal, 99(5), 40-46.

Tobias, S., \& Carlson, J. E. (1969). Brief report: Bartlett's test of sphericity and chance findings in factor analysis. Multivariate Behavioral Research, 4(3), 375-377. doi:10.1207/s15327906mbr0403_8 PMID:26745847

Toepoel, V., \& Dillman, D. (2008). Words, Numbers and Visual Heuristics in Web Surveys: Is there a Hierarchy of Importance?

Trusov, M., Bucklin, R. E., \& Pauwels, K. (2009). Effects of word-of-mouth versus traditional marketing: Findings from an internet social networking site. Journal of Marketing, 73(5), 90-102. doi:10.1509/jmkg.73.5.90

Tsinakos, A. (2006). Collaborative Student Modelling - A new Perspective using Wiki. WSEAS TRANS on Advance in Engineering Education, 6(3), 475-481.

Umbach, P. D. (2004). Web Surveys. Best PracticesNew Directions for Institutional Research, (121), 23-38. doi:10.1002/ir.98

Velasquez, A., Graham, C., \& McCollum, K. (2009). Online Social Networking Used to Enhance Face to Face and Online Pre-Servicve Teacher Education Courses. Paper presented at the Society for Information Technology and Teacher Education International Conference.

Vereecken, W., Van Heddeghem, W., Colle, D., Pickavet, M., \& Demeester, P. (2010). Overall ICT Footpring and Green Communication Technologies. Paper presented at the Proceedings of the 4th International Symposium on Communications, Control and Signal Processing, ISCCSP 2010, Limassol. doi:10.1109/ISCCSP.2010.5463327

Wallace, C. S., \& Brooks, L. (2015). Learning to Teach Elementary Science in an Experiential, Informal Context: Culture, Learning, and Identity. Science Education, 99(1), 174-198. doi:10.1002/sce.21138

Wang, H. (2008). Wiki as a Collaborative Tool to Support Faculty in Mobile Teaching and Learning. Paper presented at the Society for Information Technology \& Teacher Education International Conference 2008, Las Vegas, NV. Retrieved from http://www.editlib.org/p/27658 
Waters, R. D., Burnett, E., Lamm, A., \& Lucas, J. (2009). Engaging stakeholders through social networking: How nonprofit organizations are using Facebook. Public Relations Review, 35(2), 102-106. doi:10.1016/j. pubrev.2009.01.006

Waycott, J., Bennett, S., Kennedy, G., Dalgarno, B., \& Gray, K. (2010). Digital divides? Student and staff perceptions of information and communication technologies. Computers \& Education, 54(4), $1202-1211$. doi:10.1016/j.compedu.2009.11.006

Williams, B., Onsman, A., \& Brown, T. (2010). Exploratory factor analysis: A five-step guide for novices. Australasian Journal of Paramedicine, 8(3).

Young, K., \& Rodger, R. (1998). The relationship between depression and Internet addiction. Cyberpsychology (Brno), 1(1), 25-28. doi:10.1089/cpb.1998.1.25

Zhu, D. H., Chang, Y. P., Luo, J. J., \& Li, X. (2014). Understanding the adoption of location-based recommendation agents among active users of social networking sites. Information Processing \& Management, 50(5), 675-682. doi:10.1016/j.ipm.2014.04.010 
Tomayess Issa is a Senior Lecturer at the Faculty of Business and Law, Curtin University/Australia. Tomayess completed her doctoral research in Web Development and Human Factors. As an academic, she is also interested in establishing teaching methods and styles to enhance the students'learning experiences and resolve problems that students face. Tomayess is a Conference and Program Co-Chair of the IADIS International Conference on Internet Technologies and Society and IADIS International Conference on International Higher Education. Furthermore, she initiated the IADIS conference for Sustainability, Green IT and Education. Currently, she conducts research locally and globally in Human-Computer Interaction, Usability, Social Networking, Sustainability, Sustainable Design, Green IT, Cloud Computing and Teaching and Learning. Tomayess has published her work in several peer-reviewed journals, books, book chapters, papers and research reports and participated in local and global conferences. Tomayess edited several books, and special journal issues with prestige publishers; and her work is taught in postgraduate and undergraduate units. Tomayess was a coordinator of the International Research Network (IRNet-EU, Jan2014 - Dec 2017) the aim of which was to study and develop new tools and methods for advanced pedagogical science in the field of ICT instruments, e-learning and intercultural competencies. Tomayess is a senior research member of ISRLAb (Information Society Research Lab) for the International Association for Development of the Information Society. Finally, Tomayess has supervised PhD, Master of Phil and Master Dissertations; and she has received Curtin Guild Awards for her teaching and supervision. In 2017, she was the overall, university-wide winner of the Student Guild Outstanding Achievement in Teaching Excellence 2017 Award.

Sulaiman Alqahtani is currently doing his research in information systems with an emphasis on the intersection between technology and culture. Sulaiman has a special interest in information systems in relation to security knowledge with a double major bachelor's degree in (Business Information Systems) and (Cyber Forensics Information Security Management) and Masters of Commerce (information systems).

Theodora Issa is a Multi-Award winner, and a Senior Lecturer at the Curtin Business School, Curtin University, Australia. Currently, Theodora is conducting her post-doctoral research on ethical mindsets, spirituality and aesthetics. Theodora is one of the webmasters of her community's website (since 1995) and is one of the editors of the weekly bulletin since 1995. Theodora is an active member at the World Council of Churches (a) delegate, 2012, (b) member of Central Committee November 2013, and, (c) member of Education and Ecumenical Formation Commission June 2014, and (d) member of The Permanent Committee on Consensus and Collaboration June 2016.

Noorminshah A. lahad is a Senior Lecturer at the Information Systems Department, Faculty of Computing at the Universiti Teknologi Malaysia (UTM). She received herPhD degree from the University of Manchester, United Kingdom. Her research interests are on Social Media Continuance Use, Computer Supported Project Based Learning \& Health Informatics. She has led various research projects and won research awards nationally and internationally. She is the Secretary of the Association for Information Systems (Malaysia Chapter) and a member of IEEE Computer Society, Malaysia.

Peldon Peldon completed her Master of Commerce (Information Systems) from Curtin University in 2013. Peldon is Sr. ICT Officer in Jigme Dorji Wangchuck National Referral Hospital- Thimphu, Bhutan since 2009. She completed a Master Dissertation entitled: Examining the Risks and Opportunities of Social Networking Adoption in Health Care System in Bhutan and is author of chapter The Evolution of the Internet in the Business Sector: Web 1.0 to Web 3.0 (2015) and co-author of Examining the Risks of Social Network Adoption in the Bhutanese Health Care System, The International Journal of Web Based Communities (2014).

Sooyoung Kim is an assistant professor at Seoul Women's University. She is in charge of developing and teaching character education programs for female college students with the purpose of raising future female leaders equipped with expertise and character. Her research interests are in character education, career adaptability, mentoring of future woman leaders, motivation, meta-cognition and social networking systems for education. She has served as a reviewer for several journals and conference papers (such as International Human Resource Management, Learner Centered Curriculum Studies, AHRD conference papers). She received her PhD degree in HRD from the University of Illinois at Urbana-Champaign.

Samant Saurabh did his B. Tech in Electronics and Communication Engineering from Indian Institute of Technology, Guwahati, India and MS in Department of Electrical and Computer Engineering, University of Massachusetts Amherst, USA. He has worked for as software engineer in multi-national companies like Cisco and Sun Micro Systems. Presently, he is working as Assistant Professor in Department of Computer Science and Engineering, at Birla Institute of Technology, Mesra. He is also a PhD candidate in the Department of Computer Science at Indian Institute of Technology, Patna. His areas of interest are Computer Networks, Operating Systems and Algorithms.

Sumaiya Pervaizz completed her BS (Hons) in computer science from Peshawar University, Pakistan. After that she completed two masters from Curtin University, first in Project management and later on Master of Commerce (information system). During, the Master of Commerce (information system) she completed a dissertation entitled: "The advantages and risks of using social networking in higher education in Pakistan," which was also published as a book chapter "Social Networking and education global perspectives" as a chapter in 2015. Currently, Sumaiya is completing another degree from Curtin University which is Master of philosophy (information system) and her research topic is "A new model for social networking implementation in higher education in Pakistan". 
Sun Joo Yoo is an Instructor at the College of Education, Seowon University. She was a HR Principal Consultant at Samsung SDS. She earned her doctoral degree from University of Illinois at Urbana-Champaign. Her research interests include performance consulting, design on-off line learning environments, instructional technologies, and organizational climate and culture. She has published papers in Educational Technology \& Society, Innovations in Education \& Teaching International, The Internet \&Higher Education, Human Behavior in Computers, Knowledge Management \& E-Learning and among others. She also serves on the editorial board and reviewer of several international journals including Knowledge Management \& E-Learning, and Educational Technology \& Society. More details can be found at https://www.linkedin.com/in/sunjooyoo. 